\title{
A CRITICAL ANALYSIS OF NAMIBIA'S PUBLIC PROCUREMENT SUPPLIER REMEDIES REGULATORY FRAMEWORK: INTRODUCING THE STANDSTILL PERIOD
}

\section{Ester Ndapepwa Kuugongelwa}

\author{
(2015) 2 APPLJ 59
}

\section{ABSTRACT}

In public procurement, review bodies have generally been prohibited from interfering with concluded contracts. This is particularly so as time is of the essence in the procurement process and any disruptions delay the implementation of government contracts. Delays are undesirable as they lead to the inflation of costs, which at the end of the day government has to incur. The procuring process involves the high expenditure of public funds and requires it to be used in a manner that ensures that public money is not wasted. The disruption that comes with supplier remedies therefore has to be regulated to ensure it remains minimal while affording suppliers with the right to justice. It is for this reason that the standstill period was created in the European Union (EU) to set a time limit within which unsuccessful suppliers who feel that the correct procedures were not followed can lodge their complaints before the contract is concluded. Once the time period has lapsed, contracts awarded can then be concluded between the government and the successful supplier. Challenges to the concluded contract are prohibited after this. The implementation of the contract awarded is, in other words, allowed to run smoothly with no interruptions.

At present, Namibia has no standstill period in place. Section 16 (2) of the Tender Board of Namibia Act 16 of 1996, allows for the contract awarded to be concluded immediately after notification to the successful supplier. This concluded contract can thus be challenged by unsuccessful suppliers who feel aggrieved and as a result disrupt the implementation of contracts awarded. Furthermore, Namibia has no administrative supplier remedies in place and judicial review, which involves court interference, is the only supplier remedies available to suppliers. Judicial review is however not suitable as it leads to high legal fees and delays which have a negative impact on the procurement process as a whole. Following the introduction of the standstill period in the EU, it has been adopted by some African countries. This paper looks at whether the standstill period should be introduced in Namibia, together with a specific procurement review structure as can be found in the procurement systems of other jurisdictions. Furthermore, the paper will look at how such a standstill period will work, should it be introduced, in order to reduce procurement court cases as they are clearly not ideal. 


\title{
A CRITICAL ANALYSIS OF NAMIBIA'S PUBLIC PROCUREMENT SUPPLIER REMEDIES REGULATORY FRAMEWORK: INTRODUCING THE STANDSTILL PERIOD
}

\author{
Ester Ndapepwa Kuugongelwa \\ BJuris (UNAM); LLB (UNAM); LLM (Stellenbosch) \\ APLU - Research Associate (Namibia)
}

\section{Introduction}

In public procurement, review bodies have generally been prohibited from interfering with concluded contracts. This is particularly so as time is of the essence in the procurement process and any disruptions delay the implementation of government contracts. Delays are undesirable as they lead to the inflation of costs, which at the end of the day government has to incur. The procuring process involves the high expenditure of public funds and requires it to be used in a manner that ensures that public money is not wasted. The disruption that comes with supplier remedies therefore has to be regulated to ensure it remains minimal while affording suppliers with the right to justice. It is for this reason that the standstill period was created in the European Union (EU) to set a time limit within which unsuccessful suppliers who feel that the correct procedures were not followed can lodge their complaints before the contract is concluded. Once the time period has lapsed, contracts awarded can then be concluded between the government and the successful supplier. Challenges to the concluded contract are prohibited after this. The implementation of the contract awarded is, in other words, allowed to run smoothly with no interruptions.

Following the introduction of the standstill period in the $\mathrm{EU}$, it has been adopted by some African countries. However, at present, Namibia has no standstill period in place. Section 16 (2) of the Tender Board of Namibia Act 16 of 1996, allows for the contract awarded to be concluded immediately after notification to the successful supplier. This concluded contract can thus be challenged by unsuccessful suppliers who feel aggrieved and as a result disrupt the implementation of contracts awarded. Furthermore, Namibia has no administrative supplier remedies in place and judicial 
review, which involves court interference, is the only supplier remedies available to suppliers. Judicial review is however not suitable as it leads to high legal fees and delays which have a negative impact on the procurement process as a whole.

This paper looks at whether the standstill period should be introduced in Namibia, together with a specific procurement review structure as can be found in the procurement systems of other jurisdictions. Furthermore, the paper will look at how such a standstill period will work, should it be introduced, in order to reduce procurement court cases as they are clearly not ideal.

\section{Background}

Public procurement has been defined as the "process through which the state acquires goods, works and services needed to fulfil its public functions". ${ }^{1}$ The functions referred to cover a wide range of transactions such as acquiring office furniture, the acquisition of complex military equipment needed for state defence, the construction of dams, hospitals, schools and transport means, just to mention a few. ${ }^{2}$

This practice has been around for centuries as it dates back to around 2400 and 2800 BC where the earliest procurement order was found in Syria. ${ }^{3}$ The practice spread throughout the world with no official procurement officials to administer the practice and hence the lack of any centralised procurement. ${ }^{4}$ In 1810, Oklahoma of the United States was the first state government to procure centrally by creating a board to procure for all state departments and agencies. ${ }^{5}$ Since then centralised purchasing has gradually become common in state and local governments across the world as practiced today. ${ }^{6}$

The transactions referred to are done for the benefit of the citizens of a state as they are usually the ultimate beneficiaries of such goods and services. ${ }^{7}$ The transactions take place between government and outside bodies that supply such goods and services. Arrowsmith, Linarelli and Wallace ${ }^{8}$ state that procurement entails

\footnotetext{
${ }^{1}$ Quinot \& Arrowsmith 2013:1.

2 Arrowsmith et al 2000:1.

3 Thai 2001:11.

411.

512 (reference in main text omitted).

612.

7 Arrowsmith et al 2000:9.

86.
} 
the public body obtaining goods and services that it needs by entering into contracts with an outside body, which consists of various entities such as companies under the private sector. The process therefore involves the purchasing of items from a market in which the government is the purchasing body and the market consisting of various suppliers to select from. ${ }^{9}$ The objective here is to achieve value for money which is considered the key objective of public procurement regulation. ${ }^{10}$ This objective consists of three aspects of which the first is ensuring that the goods, works and services are appropriate. ${ }^{11}$ Secondly, concluding an agreement to secure what is required on the best possible terms and lastly, ensuring that the contracting partner is able to provide such goods, works or services on the agreed terms. ${ }^{12}$ In order to achieve value for money, the contracting authorities are required to purchase through some competitive method which allows for multiple suppliers to compete for the contract. ${ }^{13}$ The United Nations Commission on International Trade Law provides for the Model Law on Public Procurement (UNCITRAL Model Law), ${ }^{14}$ which sets international standards in respect of public procurement. The Model Law requires the fair and equal treatment of suppliers when competing for such contracts which are often referred to as tenders. ${ }^{15}$

The funds used by government and its agencies for public procurement are derived from taxpayers and in some instances from international funding agencies. ${ }^{16}$ It is for this very reason that government and its agencies are required to make use of such public funds "to secure the best possible value for money in the way goods and services are obtained, to ensure that public money is not wasted." ${ }^{17}$ Furthermore, it is no secret that resources are limited, especially on the African continent and hence the importance of making sure that public funds are used for their intended purposes and are not wasted on unnecessary costs. To ensure that the funds are used accordingly and tenders are awarded accordingly, rules have been set in place. ${ }^{18}$ Appropriate rules

\footnotetext{
9 Trepte 2004:35.

${ }^{10}$ Quinot \& Arrowsmith 2013:8.

119.

129.

139.

14 United Nations Commission on International Trade Law (UNCITRAL) Model Law on Public Procurement 2011.

15 UNCITRAL Model Law Preamble para (d).

${ }^{16}$ Arrowsmith et al 2000: 9.

178.

${ }^{18}$ Arrowsmith 2005:1363.
} 
set in place for an effective procurement system are however not sufficient. There must be steps available to be taken to ensure that they are applied correctly and these are the supplier remedies. ${ }^{19}$ As stated by Quinot, ${ }^{20}$ designing effective supplier remedies is not enough as success largely depends on the effective implementation of the remedies. Effective enforcement mechanisms are in other words required for an efficient procurement system and include remedies which are both administrative and private in nature. ${ }^{21}$ Procurement is largely based on the principle of cost-effectiveness which means that the execution of a procurement contract must ensure the attainment of value for money. ${ }^{22}$ In order to achieve this, enforcement mechanisms should ensure that contractual disputes are resolved swiftly and in the most efficient manner.

According to Trepte, ${ }^{23}$ recent years have globally witnessed extraordinary growth in procurement regulation at both national and international levels. This includes the various legal remedies that have been developed to enforce public procurement rules and play a vital role in protecting suppliers. Setting in place protective mechanisms is particularly important where competitive tendering is used as a method to procure goods in order to balance the unequal power amongst suppliers and afford each supplier with an equal opportunity. ${ }^{24}$ Other reasons include the importance of maintaining public confidence in government because this affects the quality of goods offered. ${ }^{25}$ If suppliers have confidence in government with respect to the fact that there is an equal opportunity for every supplier, this encourages more suppliers to participate. The increased participation means higher competition, which leads to the increased quality of goods as suppliers will aim to tender the best products to increase their chances of being awarded the contract. ${ }^{26}$

The European Union (EU) has had to deal with relatively the same procurement issues faced by other public institutions around the world and has certainly created the most comprehensive public procurement regime which should serve as a guiding mechanism for countries developing their own procurement regimes. ${ }^{27}$ This regime is

\footnotetext{
19 Arrowsmith et al 2000:749.

20 Quinot 2013:308.

21 Arrowsmith 2005:1363.

22 Bolton 2007: 348.

23 Trepte 2004:1.

24 Bolton 2007:317.

25317.

${ }^{26}$ Arrowsmith et al 2000:19.

27 Arrowsmith 2009: 252.
} 
referred to as the European Community (EC) and is one of the three pillars of the EU. ${ }^{28}$ The Public Contracts Directives (2014/24/EU) sets out the legal framework for public procurement in the EU and applies to all member states. ${ }^{29}$ The purpose of the EU procurement rules is to open up the public procurement market and to ensure the free movement of supplies, services and works amongst its member states. ${ }^{30}$ All member states are required to domesticate the rules and therefore the implementation is done at national level. ${ }^{31}$ There are two main enforcement mechanisms in this system namely the Remedies Directives and the European Commission. The Remedies Directives coordinate national review systems by imposing common standards meant to ensure that rapid and effective means of redress are available in all the member states in cases where suppliers allege that contracts have been awarded without following the correct procedures. ${ }^{32}$ The Commission on the other hand has a general duty of ensuring that member states adhere to the rules. ${ }^{33}$ The Court of Justice of the EU has also been highly aware of the importance of effective enforcement in the field of public procurement and therefore it has interpreted the law in a dynamic manner in a number of landmark cases leading to fundamental improvements of the current enforcement system. ${ }^{34}$

Under the EU regime, an important rule, which was based on a principle developed in case law of the Court of Justice and has been regarded to be of utmost importance for the effective enforcement of public procurement rules, was developed. ${ }^{35}$ This rule, called the "Standstill period rule", requires suppliers to be given sufficient time to examine the contract award decision and to assess whether it is appropriate to initiate a review procedure before the conclusion of the contract. ${ }^{36} \mathrm{~A}$ review procedure is followed where it is alleged that the procuring authorities have not followed the correct procedure set in place for procuring goods or services. The rule was developed in the case of Alcatel Austria $A G$ and Others $v$ Bundeministerium fur Wissenschaft und Verkehr ${ }^{37}$ (Alcatel), which dealt with the Austrian procurement system in which

\footnotetext{
28252.

${ }^{29}$ Crown Commercial Service, 2014:2.

302.

313.

32 European Commission, 2015.

33 Arrowsmith 2009:252.

34 Treumer 2011:17.

3548.

3648.

37 Case C - 81/98.
} 
challenges to concluded contracts were prohibited and remedies were only limited to damages. ${ }^{38}$ The contract was concluded at the moment the successful supplier was notified, with no obligation to inform the unsuccessful suppliers before the conclusion of such a contract. ${ }^{39}$

The facts of the case are the following. In May 1996 the Austrian Federal Ministry of Science and Transport, the contracting authority, advertised an invitation to tender for the installation on the Austrian motorway network of an electronic system for the automatic transmission of some data. On 5 September 1996 the contract was awarded to the successful supplier and signed on the same day. ${ }^{40}$ The other unsuccessful suppliers only learned of the contract through the press. ${ }^{41}$ On 18 September 1996, the Bundesvergabeamt dismissed applications for interim measures to suspend performance of the concluded contract as this was prohibited..$^{42}$ Then, in its decision in the main proceedings on 4 April 1997, it held that there had been various breaches of the Federal Procurement Law (Bundesvergabegesetz). The decision by the Bundesvergabeamt of 18 September 1996 was set aside by the Verfassungsgerichtshof (Constitutional Court), as a result of which the Bundesvergabeamt quashed its decision of 4 April 1997 and made an interim order prohibiting further performance of the contract. ${ }^{43}$ The interim order was made provisionally inoperative by a decision of the Constitutional Court of 10 October 1997. By order of 3 March 1998 the Bundesvergabeamt referred certain questions concerning the review directive to the Court of Justice for a preliminary ruling. ${ }^{44}$

The Constitutional Court ruled that this system violated the Directive's general obligation to provide effective remedies. ${ }^{45}$ This is due to the fact that suppliers were not given the right to remedies because contracts were concluded immediately and challenging a concluded contract was not allowed. The decision in Alcatel meant that in states where the setting aside of contracts concluded is prohibited, a reasonable delay between notifying suppliers of the award decision and concluding the contract

\footnotetext{
38 Arrowsmith 2009:282.

39282.

40 Alcatel Austria AG and Others v Bundesministerium fur Wissenschaft und Verkehr C - 81/98, para 3.

41 Para 3.

42 Para 4.

43 Para 5.

44 Para 6.

45 Arrowsmith 2009:282.
} 
had to be provided for to allow time for legal challenges. ${ }^{46}$ The European Commission in its 2006 proposal suggested including an express requirement in the Remedies Directive for at least a ten-day delay. ${ }^{47}$ As a result, the standstill period was introduced by Directive 2007/66/EC and member states were required to implement this rule into their national laws by 20 December 2009. ${ }^{48}$ Since then, the Remedies Directive has not changed and thus the standstill rules are basically still the same. ${ }^{49}$ The development of the standstill period rule led to other procurement systems outside the European regime adopting the same approach. Some African countries such as Ethiopia, Rwanda and Kenya have also adopted this rule applying different standstill periods. ${ }^{50}$

\section{Standstill periods}

In some countries, there is no mandatory standstill period and therefore challenges to already concluded contracts are allowed, which may result in the granting of interim relief such as automatic suspension of the contract or the invalidation of a concluded contract. $^{51}$ This disrupts the procurement process and is undesirable. This is the case in Namibia. Namibia's public procurement process is regulated by the Tender Board of Namibia Act 16 of 1996. Section 16 of the Act provides for the acceptance of tenders and entry into force of agreements. It provides for the conclusion of a contract between the procuring entity and the successful supplier immediately after the successful supplier has been notified about winning the tender. This can be inferred from the wording of subsection $2 .{ }^{52}$ There is no provision providing for a mandatory period to be observed by all parties involved before the conclusion of the contract. The effect of this is that no period is provided to verify whether the procedure followed leading up

\footnotetext{
46282.

47282.

48 Remedies Directive 2007/66/EC Art 3.

49 Crown Commercial Service, 2015:3.

50 Quinot 2013:318.

51318.

$52 \mathrm{~S} \mathrm{16(2)} \mathrm{states} \mathrm{that} \mathrm{"Where} \mathrm{in} \mathrm{terms} \mathrm{of} \mathrm{a} \mathrm{title} \mathrm{of} \mathrm{tender} \mathrm{-} \mathrm{(a)} \mathrm{a} \mathrm{written} \mathrm{agreement} \mathrm{is} \mathrm{required} \mathrm{to} \mathrm{be}$ concluded after the acceptance of a tender, the Board and the tenderer concerned shall, within 30 days from the date on which that tenderer was notified accordingly enter into such an agreement or within such extended period as the Board may determine, enter into such an agreement; (b) a written agreement is not required to be so concluded, an agreement shall come into force on the date on which the tenderer concerned is notified of the acceptance of his or her tender."
} 
to the award of a contract is indeed the correct procedure before concluding the contract.

Unsuccessful suppliers who wish to challenge the award can therefore do so, even after the contract has already come into force. This, however, can only be done through judicial review which means approaching the courts on an urgent basis. This is due to the fact that Namibia provides no challenge mechanisms at an administrative level. However, judicial review as the only mechanism, leads to an inefficient procurement system where delays occur as the timely implementation of projects is affected. ${ }^{53}$ By the time an aggrieved supplier seeking redress approaches the courts, the contract may have been concluded between the procuring entity and the successful supplier. The successful supplier, at this stage, would clearly have begun with preparations to start off the implementation of the contract concluded which involves financial costs. A successful supplier whose contract is set aside due to such a court challenge, although not adequately protected, is entitled to seek redress in the form of compensation although this only happens in limited cases. ${ }^{54}$ This is however not ideal as the government now has to spend more public funds on matters that are of no benefit to taxpayers such as legal fees and compensation for the aggrieved parties affected such as the initial successful supplier. Other costs include those that arise from delays in the implementation of projects as a result of court interferences.

It is clear that in the EU the standstill period was introduced to afford suppliers with sufficient time to examine the contract award decision in order to decide whether it is necessary to initiate review or not before the entry into force of a contract awarded. ${ }^{55}$ This was argued on the basis that individuals of any society are entitled to enforce their rights afforded to them by the legislators and the standstill period is a vital component of enforcing such rights in any system that provides for remedies. ${ }^{56}$ Once the standstill period has lapsed, the contract is then concluded and no challenges are allowed after its entry into force. This is not the case in Namibia as concluded contracts are challenged which lead to various problems which will be further discussed in detail in this paper. This paper will therefore look at whether the standstill period should be introduced in Namibia, together with a specific procurement review structure as can

\footnotetext{
${ }^{53}$ Graig, 2014.

${ }^{54}$ See for example Bolton 2013:184 on the position in South Africa.

55 Treumer 2011:48.

5649.
} 
be found in the procurement regimes of other jurisdictions. Suppliers in this way will have a limited time to challenge proceedings and after such a period has lapsed the contract will be concluded and thereafter no challenges will be allowed in order to minimise the waste of government resources. Furthermore the paper will look at how such a standstill period will work, should it be introduced, ie what shall be done during such a standstill period in order to reduce procurement court cases as they are clearly not ideal.

\section{Namibia's Procurement Regulatory Framework}

\section{Background to Namibia's Public Procurement Regime}

Namibia was colonised by Germany in 1884 and became known as Germany South West Africa. ${ }^{57}$ German rule in Namibia effectively ended with the surrender of the German armed forces on 9 July 1915. ${ }^{58}$ On 28 October 1915, Namibia, then known as South West Africa (SWA) became a protectorate of South Africa in terms of the Peace of Treaty of Versailles. ${ }^{59}$ In terms of this treaty, South Africa was simply given the mandate to administer Namibia until such a time it could govern itself. In 1921, a Commission on South West Africa established by the South African government recommended that Namibia be administered as a "fifth province" of South Africa ${ }^{60}$ and thus making South African laws applicable to Namibia. Public procurement was therefore regulated by the South West Africa Tender Board established under section 26A of the Finance and Audit Ordinance 1 of $1926 .{ }^{61}$ These laws were based on apartheid laws that discriminated against black people and therefore left huge economic imbalances. ${ }^{62}$ In 1990, led by the South West Africa People's Organisation (SWAPO), Namibia finally gained its independence from the South African apartheid regime and planned to replace the oppressive colonial legislation and practices with new laws. ${ }^{63}$ Since then the Namibian government has enacted several pieces of legislation in favour of previously disadvantaged people.

\footnotetext{
57 Hayes et al 1998:4.

58 Namlex, 2010:8.

59 Kangumu 2011:47.

60 Namlex, 2010:8.

${ }^{61}$ Tender Board of Namibia Act 16 of 1996 s 2(2).

62 Jauch et al, 2011:188.

63 International Labour Organisation and the African Commission on Human and People's Rights, 2008:5.
} 
Today, Namibia is classified as an upper-middle income country with a population of 2.4 million $^{64}$ and makes use of public procurement to redress economic imbalances left behind by the apartheid regime. ${ }^{65}$ As previously mentioned, public procurement in Namibia is regulated by the Tender Board of Namibia Act. ${ }^{66}$ The Act establishes the Tender Board of Namibia, which is the statutory mandated authority with jurisdiction over public procurement and is made up of Permanent Secretaries form each ministry who chair the Board. One staff member from each office, ministry and agency of government and two other persons appointed by the Minister of Finance also sit on the Board. ${ }^{67}$ The Board is entrusted to regulate and oversee the procurement function of the Namibian government. ${ }^{68}$ This is done with the objective of obtaining value for money as it is the primary objective of public procurement regulation. ${ }^{69}$ The powers and functions of the Board are provided for by section 7 of the Act and states that the Board is responsible for the procurement of goods and services for the government and for the arrangement of the letting or hiring of anything or the acquisition or granting of any right for or on behalf of the government, and for the disposal of government property. ${ }^{70}$ The Board is placed under the Directorate of Administration of the Ministry of Finance. ${ }^{71}$ It is therefore an administrative body and is expected to carry out its mandate in terms of administrative principles which is in a fair, reasonable and lawful manner. ${ }^{72}$

The Namibian government further uses public procurement to achieve socioeconomic objectives, which are commonly referred to as "horizontal" policies. ${ }^{73}$ This practice is a widely accepted tool of public procurement and has been around for a long time and includes objectives such as poverty alleviation by reducing the unemployment rate and providing equal opportunities to groups from previously disadvantaged communities such as women and youth through economic

\footnotetext{
64 The World Bank Group, 2015.

${ }^{65}$ Amoo \& Dicken 2013:124.

${ }^{66}$ Act 16 of 1996.

67 Tender Board of Namibia Act 16 of 1996 s 3.

68 Amoo \& Dicken 2013:126.

69 Quinot \& Arrowsmith 2013:8.

70 Tender Board of Namibia Act 16 of 1996 s 7(1).

${ }^{71}$ Amoo \& Dicken 2013:129.

72 Art 18 of the Constitution of the Republic of Namibia provides that "All administrative bodies and administrative officials shall act fairly and reasonably and comply with the requirements upon such bodies and officials by common law and any relevant legislation...".

${ }^{73}$ Arrowsmith \& Kunzlik 2009: 9.
} 
empowerment. ${ }^{74}$ The legal mechanisms used to achieve these objectives include reservations in the form of set asides where certain low value contracts are strictly set aside for Small Medium Enterprises (SMEs) and preferential schemes being the most common mechanisms and in particular price preference at the award stages. ${ }^{75}$ Namibia too has adopted this practice as the Board is required to give effect to the price preference policy of the government to redress social, economic and educational imbalances when comparing tenders. ${ }^{76}$

\section{Procuring Entities and Sources of Law}

According to Arrowsmith ${ }^{77}$ any country that decides to regulate public procurement must decide which transactions will be covered under its public procurement laws. The question that needs to be answered is thus: what exactly falls under the term 'public' for it to be regulated under public procurement. The answer to this question will determine which entities will fall under public procurement regulation and therefore be referred to as the procuring entities. The procuring entities in Namibia are currently classified into five groups, namely central government, regional councils, local authorities, statutory bodies and state-owned enterprises. ${ }^{78}$ The procurement rules and procedures are all regulated independently from one another and therefore are provided separately for the mentioned levels of government. The reason behind this is that a state is allowed to apply different procurement rules and procedures to different categories of entities according to the nature or degree of control that it may deem appropriate for a particular entity. ${ }^{79}$ The sources of public procurement are therefore listed as the following in Namibia: ${ }^{80}$

- The Constitution of the Republic of Namibia, 1990

- $\quad$ The Tender Board of Namibia Act ${ }^{81}$

\footnotetext{
${ }^{74}$ Quinot 2013: 370.

75382.

76 Tender Board of Namibia Act 16 of 1996 s 15(5).

77 Arrowsmith et al 2000:323.

78 Amoo \& Dicken 2013:131.

79 Arrowsmith et al 2000:336.

80 Amoo \& Dicken 2013:128.

81 Tender Board of Namibia Act 16 of 1996.
} 
- $\quad$ The Tender Board Regulations ${ }^{82}$

- $\quad$ The Tender Board of Namibia Code of Procedure 191 of 1997

- The Regional Council Tender Board Regulations ${ }^{83}$

- The Local Authority Tender Board Regulations ${ }^{84}$

- The Common Law

The rules and procedures for the procurements of goods and services by government, its organs and other entities such as local government are therefore governed by the above legislation. ${ }^{85} \mathrm{It}$ is important to note that although all agencies of government are subject to the Tender Board of Namibia Act, section 21 exempts the Namibian Defence force and the Namibia Security Intelligence Agency from the provisions of the Act when these entities are procuring security related goods, services and properties. Parastatals are also exempted as state-owned enterprises are not provided for under the regulations for central, regional and local government. ${ }^{86}$ These entities have their own rules and regulations that govern the tendering process. ${ }^{87}$ The new Procurement Bill however intends on changing this as it will cover all public entities which include state-owned enterprises. ${ }^{88}$ This will be done with the view of harmonising procurement procedures in all government entities and to better leverage the strategic importance of public procurement in achieving the socio-economic objectives of Namibia. ${ }^{89}$ The current regulatory framework only governs the process leading up to the award of contracts as there are no provisions for the position following the award of the tender. ${ }^{90}$ It is for this reason that once a tender has been awarded in compliance with the statutory provisions, all the remedies sought after are regulated by the law of contract and the law of delict. ${ }^{91}$

\footnotetext{
82 GN R 237 in GG 1403 of 02-09-1996.

83 GN R 43 in GG 2492 of 05-03-2001.

${ }^{84}$ GN R 30 in GG 2486 of 15-02-2001.

85 Amoo \& Dicken 2013:129.

${ }^{86} 133$.

87129.

88 Procurement Bill (Namibia) s 1.

89 New Era Staff Reporter, 2015.

90 Amoo \& Dicken 2013:129.

91129.
} 


\section{Procurement Procedure}

Generally, public procurement takes place through contractual arrangements and therefore the term procurement can broadly be used to refer to the whole contracting process from the specification of goods and services required and selecting a supplier all the way through to the administration and termination of the contract. ${ }^{92}$ As stated before, the Tender Board is responsible for the procurement of goods and services on behalf of the Namibian government provided that the tender amount is above the threshold of $\mathrm{N} \$ 10000.00 .{ }^{93}$ This means that although other offices, ministries and agencies of government may have capable personnel to conduct the low-value procurement, once the threshold is exceeded, the procurement process must pass through the Tender Board. ${ }^{94}$ Once it has been identified which goods or services are required, the Board starts off with the planning stage. The planning of procurement is described as a crucial early step in the procurement process. ${ }^{95}$ This is due to the fact that that inadequate planning results in the waste of resources and disputes with suppliers over ambiguous terms specified in the contract which all lead to inefficiency. ${ }^{96}$ Adequate planning increases the prospects of success in the procurement process and value for money as resources are properly made use of this way. ${ }^{97}$

Section 11 of the Act then comes into play, which provides for the invitation of tenders to be published in the Government Gazette and at least once in each of the newspapers contracted by the government. Tenders are currently advertised through New Era and on the Ministry of Finance's website on a weekly basis. ${ }^{98}$ Namibia has since independence pursued a free market economy. ${ }^{99}$ Individuals under a free market economy are free to pursue their self-interests without government restrictions even though there are substantial levels of government activity in the provision of collecting goods and services, the redistribution of income through taxes and transfer payments and the regulation of markets, notably to correct market failures. ${ }^{100}$ It therefore makes

\footnotetext{
92 Arrowsmith 2005:1.

93 Tender Board of Namibia Act 16 of 1996 s 17(1)(a).

94 Amoo \& Dicken 2013:136.

95 Arrowsmith et al 2000:355.

96355.

97355.

98 Amoo \& Dicken 2013:136.

99 Belda 2007:76.

100 Trepte 2004:19.
} 
it possible for all prospective suppliers to participate. ${ }^{101}$ In line with this, the Act requires open tendering system as the main method of tendering in Namibia which allows for all suppliers to participate. ${ }^{102}$ The closed-tender method is also made use of where only pre-qualified companies who meet all requirements are invited to tender. ${ }^{103}$

The open tendering method is however viewed as an obstacle in achieving some of the socio-economic objectives of the Namibian government such as reducing the unemployment rate through entrepreneurship, especially amongst people from previously disadvantaged communities. People from these communities are continuously encouraged to start up SMEs. The open tendering process however presents a serious challenge for SMEs as they compete against large companies who have adequate human and financial resources to meet the technical requirements and excess capital for the execution of contracts whilst SMEs are resource constrained. ${ }^{104}$ The current Act makes no mention of reservations or the setting aside of certain tenders for SMEs. The new Procurement Bill in this regard has made provision not only for national preferences ${ }^{105}$, but also for exclusive preference to local suppliers in which the Minister may prescribe any nature of procurement supporting government programmes to be reserved exclusively for categories of local suppliers. ${ }^{106}$ This will include registered SMEs and as a result make a huge impact on their success as they are very important due to the fact that they end up being the main drivers of any economy. This can be attested to by other African countries with advanced procurement regimes such as Mauritius where the Mauritian government strongly supports its SMEs as in the year 2013 they constituted $40 \%$ of the GDP and were the main drivers of employment as they provided a living to $54 \%$ of the population. ${ }^{107}$ Apart from the open tendering method, there is little guidance provided on alternative methods of procurement and therefore the public procurement system remains open to potential abuse in this regard. ${ }^{108}$

\footnotetext{
101 Amoo \& Dicken 2013:135.

102 Tender Board of Namibia Act 16 of 1996 s 15(7).

103 Indongo et al, 2014:10. See also the Tender Board of Namibia Act s 11(b).

104 Indongo et al, 2014:20.

105 Procurement Bill (Namibia) s 71.

${ }^{106} \mathrm{~S} 72(1)$

107 Mauritius 2014:7.

108 Amoo \& Dicken 2013:136.
} 
Once tenders have been received in terms the procedures set out in the Act, the evaluation and award criteria stage follows. Section 15 provides for the examination, evaluation, comparison and non-acceptance of tenders. In evaluating a tender, the Board is required to give consideration to the capacity, experience, integrity and financial status of the supplier. ${ }^{109}$ The Board is expected to award a tender to the lowest price tender and in cases where this does not happen, it is expected that reasons for not accepting the lowest tender be kept on record by the Board. ${ }^{110}$ The evaluation and award criteria are however a problem as there are no standard bidding documents provided for. ${ }^{111}$ The current bidding documents do not follow the prescribed documents set by the UNCITRAL Model Law as they lack important features and therefore have been said to make the procurement and contract management process a problem. ${ }^{112}$ In particular, the qualification and evaluation criteria are not sufficiently outlined. Tailor-made evaluation criteria or grids have to be developed for each evaluation to identify the best technical quality and more economically priced tender. ${ }^{113}$

\section{Enforcement Mechanisms}

The UNCITRAL Model Law provides aggrieved suppliers with the right to challenge a decision or an action of a procuring body that is alleged to have not followed the correct procedures when it was taken. ${ }^{114}$ Challenge proceedings may be made by way of an application for reconsideration to the procuring authority; ${ }^{115}$ an application for review to an independent body; ${ }^{116}$ or an application to court. ${ }^{117}$ The Model Law therefore provides for challenges at an administrative level and not only at judicial level. Decisions taken in such challenge proceedings may be appealed in courts. ${ }^{118}$ The Model Law, however, is not a binding instrument and therefore countries around the world have designed their own public procurement regimes that do not entirely

\footnotetext{
109 Tender Board of Namibia Act 16 of 1996 s 15(4).

110 S 15(6).

111 Tender Board of Namibia, 2015:14.

11214.

113 Amoo \& Dicken 2013:138.

114 UNCITRAL Model Law Art 64(1).

115 Art 66.

116 Art 67.

117 Art 64(2).

118 Art 64(3).
} 
follow the provisions of the Model Law. It is for this reason that some countries have review mechanisms available at an administrative level and others not. Three primary dispute resolution mechanisms are available to aggrieved suppliers and they include internal remedies which are provided for at an administrative level, non-judicial remedies and judicial remedies which involve the courts.

In South Africa, the courts have held that the conduct of the government procurement process, the evaluation of tenders and the award of a contract to a successful supplier are forms of administrative action. ${ }^{119}$ It is on this basis that aggrieved suppliers have a right to challenge such administrative actions of government. This is also the case in Namibia in terms of Article 18 of the Constitution of the Republic of Namibia which provides suppliers with the right to challenge administrative action on grounds of fairness, reasonableness and lawfulness. Namibia has no supplier remedies at an administrative level such as a procurement review board and therefore there are no internal remedies available. ${ }^{120}$ In Namibia only two mechanisms are available, namely, judicial remedies and non-judicial remedies with judicial remedies being the commonly used mechanism which involves courts.

\section{Judicial Remedies}

These are remedies that follow only once the process of review by a competent court has taken place. ${ }^{121}$ The review procedure should therefore be seen as merely a means to obtain the necessary relief and should not be regarded as a remedy itself. ${ }^{122}$ As mentioned before, the Tender Board acts as an administrative body and persons aggrieved by the exercise of such acts and decisions have the right to seek redress before a competent court or tribunal. ${ }^{123}$ Namibian suppliers therefore only have one formal avenue to seek redress and enforce public procurement rules, which is before a competent court via judicial review. There are various forms of relief sought under judicial review which either fall under interim relief or final relief. The suppliers

\footnotetext{
119 Bolton 2007:316.

120 Quinot 2013:310.

121316.

122316.

123 Constitution of the Republic of Namibia Art 18.
} 
approach the Namibian High Court in terms of the Rules of the High Court of Namibia to seek such relief.

\section{Interim Relief}

Burns $^{124}$ defines an interim relief, or what is also referred to as temporary relief, as a relief that is designed to preserve or maintain the status quo. This involves a preliminary decision from the court pending the final decision of a full trial. ${ }^{125}$ Interim relief is a crucial component of any supplier remedies regime and requires a trade-off between preserving an effective remedy in a challenge to a procurement decision thereby promoting integrity, on the one hand, and the need to minimise disruption to the procurement process thereby enhancing efficient procurement on the other. ${ }^{126}$ Under public procurement, the interim relief sought may take the form of an order for the suspension of a contract pending finalisation of the review application. ${ }^{127}$

According to Quinot, ${ }^{128}$ a common feature in many African procurement systems is the suspension of procurement procedures when a challenge is lodged. The reviewing body has the discretion in deciding whether to order the suspension of a contract or not depending on the surrounding circumstances of each case. ${ }^{129}$ In countries where there is no independent review body for procurement, the suspension of a contract is sought at judicial level, which for example is the case in South Africa. ${ }^{130}$ This too, is the case in Namibia. ${ }^{131}$ The aggrieved supplier may ask for an interim order to suspend the procurement pending the finalisation of the review application in terms of normal interim relief rules in civil suits. ${ }^{132}$ In terms of a civil suit, the applicant has to meet three requirements when seeking an interim order. These requirements have been developed by South African case law which Namibia applies as well. As adopted from Erickson Motors (Welkom) Ltd v Protea Motors ${ }^{133}$ the applicant must show to have a prima facie right, a risk of irreparable harm if the relief is not granted and lastly prove

\footnotetext{
124 Burns 2013:564.

125564 .

126 Quinot 2013:323.

127321.

128319 .

129320 .

130321.

${ }^{131}$ Amoo \& Dicken 2013:129.

132 Quinot 2013:321.

1331973 (3) SA 685 (A).
} 
that there is no alternative remedy. The court then weighs the interests of the respective parties in granting or withholding the relief, which is the same practice followed by independent procurement review bodies. ${ }^{134}$

In practice, this is done by way of an interdict application brought on an urgent basis in terms of the Rules of the High Court of Namibia. Rule 73 makes provision for urgent applications in which the court is allowed to dispense with the forms and service provided for by these rules and deal with the application in a manner it considers fair and appropriate. ${ }^{135}$ Once a legal practitioner certifies in a certificate of urgency that the matter is urgent, the matter can be heard at any time or on any day. ${ }^{136}$ In an affidavit filed in support of the application, the applicant must set out explicitly the circumstances which he or she avers render the matter urgent ${ }^{137}$ and the reasons why he or she claims he or she cannot be afforded substantial redress at a hearing in due course. ${ }^{138}$ There are two kinds of interdicts namely prohibitory and mandatory interdicts. A prohibitory interdict has the effect of stopping an unlawful interference with a person's right or preventing threatened interference from taking place. ${ }^{139}$ The mandatory interdict is an order which requires action to be taken. ${ }^{140}$ Both interdicts can either be final or interim. ${ }^{141}$

\section{Final Relief}

In most procurement systems, the general final relief available is for the review body to review the relevant decision and set it aside when found that correct procedures have not been followed. ${ }^{142}$ This has been described to be the essential hallmark of an effective remedies system, which is the ability to have the impugned decision invalidated. ${ }^{143}$ In those systems with judicial review as the only supplier remedies available, the same approach is followed. ${ }^{144}$ Namibia's judicial review system is no exception to this as several tender challenge applications have in the past succeeded,

\footnotetext{
134 Quinot 2013:320.

135 High Court Rules of Namibia Rule 73(3).

136 Rule 73(1).

137 Rule 73(4)(a).

138 Rule 73(4)(b)

139 Hoexter 2012:559.

140559.

141559.

142 Quinot 2013:324.

143324.

144325.
} 
resulting in the invalidation and setting aside of the Tender Board's decisions. The court will therefore set aside the decision and refer the matter back to the Tender Board for reconsideration. ${ }^{145}$ Legal costs are then ordered against the party in default which in such a case may be the Ministry of Finance since the Tender Board resides under the Directorate of Administration of the Ministry of Finance. ${ }^{146}$

For a successful supplier who loses the tender due to the setting aside of the tender because of an error on the part of the Tender Board, such a supplier can also approach the courts seeking compensation if out of pocket losses were incurred. This is due to the fact that once a tender has been awarded, the remedies sought thereafter all fall under private law which provides for such claims. The law of delict and law of contract govern will therefore govern such remedies. ${ }^{147}$

\section{Non-Judicial Remedies}

There are also external bodies that play a role in enforcing procurement rules and have no direct interest in the procurement procedure compared to the parties to the procurement contract or potential parties in cases of unsuccessful suppliers who wish to challenge the procedure. In Namibia the Anti-Corruption Commission (ACC) plays a role in enforcing procurement rules. It is established under the Anti-Corruption Act 8 of 2003 and its function is to investigate matters that raise suspicion of conduct constituting or prone to corruption. ${ }^{148}$ Section 37 of the Act provides for corrupt behaviours in relation to public tenders and together with regulation 13 of the Tender Board Regulations, the ACC is empowered to investigate cases of public procurement corruption. ${ }^{149}$ The office of the Auditor-General ${ }^{150}$ and the Ombudsman ${ }^{151}$ also play a role in ensuring accountability of the public procurement regulatory system. ${ }^{152}$ The office of the Auditor General provides the National Assembly with independent financial reports on the efficiency and effectiveness with which public resources are

${ }^{145}$ CSC Neckartal Dam Joint Venture $v$ The Tender Board of Namibia \& Others, (A109/2013; A76/2013) [2013] NAHCMD 186 (4 July 2013).

146 Amoo \& Dicken 2013:126.

147129.

148 Anti-Corruption Act 8 of 2003 (Namibia) s 3.

149 Amoo \& Dicken 2013:127.

150 Established under the Constitution of the Republic of Namibia Art 127.

151 Established under the Constitution of the Republic of Namibia Art 89.

152 Amoo \& Dicken 2013:127. 
used by the Central Government and Public institutions. ${ }^{153}$ In the procurement context, an Auditor-General therefore has the power to conduct forensic investigations in determining whether the various organs of state followed procurement procedures that were cost-effective. ${ }^{154}$ The office of the Ombudsman is mandated to promote and protect human rights; fair and effective administration; and combat misappropriation or misuse of public funds through independent, impartial investigation and resolution of complaints. ${ }^{155}$ In the public procurement context, aggrieved suppliers are therefore allowed to approach this office in cases of any complaints they wish to lodge against public officials in cases of alleged irregular procedures.

\section{Evaluating Namibia's procurement regime}

Namibia's public procurement regulatory system falls short of the internationally set standards of the UNCITRAL Model Law. This is especially evident in so far as bidding documents and supplier remedies are concerned. The bidding documents are not transparent as they do not provide detailed evaluation criteria. There is also excessive reliance on judicial intervention as there are no alternative administrative review mechanisms. Judicial intervention is slow and costly and not geared towards the improvement of procurement efficacy. ${ }^{156}$ These factors have several effects on the procurement process and are discussed next.

\section{The Effectiveness of Namibia's Supplier Remedies Regime}

\section{Introduction}

The financial interests at stake, the high volume of transactions and the close interaction between the public and private sectors create multiple opportunities for private gain and waste at the expense of the taxpayer in public procurement. ${ }^{157}$ This has led to a lack of integrity being identified as one of the biggest concerns in the procurement process and as a measure to address this concern, supplier remedies

\footnotetext{
153 Office of the Auditor-General of the Republic of Namibia, 2014.

154 Bolton 2007:314.

155 Ombudsman Namibia, 2012.

156 Quinot 2013:334.

157 OECD, 2011:150.
} 
have been developed by various countries. ${ }^{158}$ These have been described as legal mechanisms that allow suppliers to challenge the public procurement decisions and obtain relief where it is proven that the correct procurement procedures have not been followed by procurement officials. ${ }^{159}$

According to Gordon, ${ }^{160}$ having supplier remedies in place bring an important measure of transparency and accountability to public procurement systems. Procurement officials and government agencies are held accountable for their actions and this is viewed as a form of good governance. ${ }^{161}$ Having supplier remedies in place is however not enough as they are required to be effective in order to achieve a cost effective procurement process. ${ }^{162}$ This means exhaustively investigating complaints made by aggrieved suppliers while minimising disruption to the procurement process. This tension between the desire to exhaustively investigate complaints by aggrieved suppliers on the one hand and the need to let the procurement process move forward swiftly on the other hand has been described as one of the biggest tensions in public procurement. $^{163}$ The judicial review as the main supplier remedies available in Namibia is therefore critically analysed in this chapter to see whether it is effective or not.

\section{The Judicial Review Process}

The judicial review process in Namibia clearly ensures the adequate enforcement of the right to administrative justice in terms of Article 18 of the Constitution of the Republic of Namibia. Aggrieved suppliers are afforded the right to challenge an award decision of the Tender Board, regardless of whether the contract has already entered into force or not. The procurement process is suspended until a decision is taken by the courts in respect of the review application. Suppliers who wish to appeal the decision of the High Court may approach the Supreme Court of Namibia. In order to

\footnotetext{
158 Quinot 2013:308.

159308.

160 Gordon 2006:428.

161430.

${ }^{162}$ Quinot 2013:309.

163 Gordon 2006:430.
} 
determine whether this judicial review process is effective or not, the effects it has on the procurement process have to be looked at. Due to several aspects such as time and costs involved, judicial review as a review mechanism in public procurement has been said to be unsuitable. ${ }^{164}$ These factors are said to defeat the principle of costeffectiveness. ${ }^{165}$ The efficiency of the judicial review process, with no provision of a standstill period, is discussed in detail below.

\section{Affordability}

First and foremost, the right to justice in any jurisdiction is only present when all its citizens have access to this right. The financial costs involved in litigation has been identified as a significant barrier in realising access to justice in Namibia as costs of legal professional services remain unaffordable for the average Namibian. ${ }^{166}$ In the public procurement context, suppliers can only be said to have this right if they all have access to judicial review to enforce their right to administrative justice. Public procurement today has become quite significant across the world and as previously mentioned, used as a policy tool to redress economic imbalances caused by past discriminatory practices. ${ }^{167}$ It is for this reason that entrepreneurship has been highly encouraged in previously disadvantaged communities to address unemployment and poverty and has resulted in the increase of procurement suppliers. This group of upcoming entrepreneurs are the average Namibians. They target small scale tenders, which of course, are the everyday tenders and hence make up the majority of tenders awarded. Should such a group wish to challenge an award, the only remedy available to them is judicial review which has been described as an expensive process which is not affordable for the average Namibian. ${ }^{168}$ This means that some suppliers are actually left with no access to the courts and therefore have no platform to enforce their right to administrative justice which is a constitutionally entrenched right.

Judicial review as the only mechanism for aggrieved suppliers is therefore not ideal in this respect as some suppliers cannot afford the legal costs involved. This can have an inverse effect on the efficiency of the procurement process as some suppliers will

\footnotetext{
164 Schimdt 2014:48.

165 Bolton 2007:384.

166 Nakuta \& Chipepera 2011:31.

167 Quinot 2013:382.

168 Nakuta \& Chipepera 2011:31.
} 
not lodge any complaints even when there are reasonable grounds to do so. Misconduct on the part of public officials may continue and this brings about a lack of integrity in the entire procurement process. The only other mechanism available to suppliers to enforce their rights outside the court system is approaching the office of the Ombudsman. ${ }^{169}$ The investigation process involved takes time before completion and it is therefore not ideal for the procurement process as further delay is caused. Reporting matters to the Anti-Corruption Commission is also not ideal as such investigations take a long time before finality is reached. ${ }^{170}$

\section{Delays}

Challenges lodged against procurement procedures delay finality in the procurement process at a potentially high cost to the procuring authority. ${ }^{171}$ For suppliers who can afford to make it to court to enforce their right to administrative justice, such a process leads to an inefficient procurement system where delays occur as the timely implementation of projects is affected. ${ }^{172}$ This arises due to the suspension of the procurement process until a decision is handed down by the courts. By the time an unsuccessful supplier approaches the courts, the award contract may have been concluded at this stage between the procuring entity and the successful supplier. Preparations would clearly be underway to begin the implementation of the contract concluded and involves financial costs. This is due to the fact that contracts are entered into immediately after notification of the award contract with no standstill period required to be observed. A perfect illustration is the case of AFS Group Namibia (Pty) Ltd v Chairperson of the Tender Board of Namibia ${ }^{173}$ in which the applicant, AFS Group Namibia, sought an order suspending the implementation of an agreement already concluded pursuant to an award of a tender pending the finalisation of the a review application made by the applicant. The agreement entered into was between the Ministry of Works and Transport and the successful supplier, DPF Energy and Minerals (Pty) Ltd, for the supply and management of EFuel for government fleet. The

\footnotetext{
16947.

170 Schimdt 2014:46.

171 Gordon 2006:437.

172 Graig, 2014.

173 (A55/2011) 2011 NAHC 184.
} 
applicant successfully lodged its application for review. The implementation of the agreement entered into was then suspended and the parties were interdicted from taking any further steps in implementing the contract pending the finalisation of the review application. The problem here is the fact that the contract has already been concluded and therefore disrupts the implementation of projects which costs money at the end of the day. The courts are also not given a time limit within which the matter should be finalised and therefore brings uncertainty as to the finalisation of the entire procurement process. This is however not ideal as the government now has to spend more public funds on matters that are of no benefit to taxpayers.

The judicial review process is also not suitable because the courts do not necessarily end up making an award, but rather nullifying the decision of the Board and refer it back to the Board for reconsideration which further delays the procurement process. ${ }^{174}$ This as well leads to high expenditure as a result of project delays. The infamous case of CSC Neckartal Dam Joint Venture $v$ The Tender Board of Namibia $\&$ Others ${ }^{175}$ is the perfect illustration in which the project for the construction of a dam was delayed due to court interference and when the contract was finally re-awarded the costs had increased. On 14 March 2013 the Tender Board (first respondent) awarded a tender to Salini SpA for the construction of the Neckartal Dam on the Fish River. The tender was in a sum excess of $\mathrm{N} \$ 2.8$ billion. After a pre-qualification process, three suppliers qualified and tendered for the project. The two unsuccessful suppliers, CSC Neckartal Dam Joint Venture (CSC) and Vinci Construction Grands Projects \& Orascom Construction Joint Venture (Vinci Orascom), each launched separate review applications to set aside the tender award based on the evaluation process. They believed that the decision by the Board to award the contract to Salini SpA was highly unjustified as Vinci-Orascom scored the highest during the evaluation process and Salini SpA the second, followed by CSC Neckartal Dam Joint Venture which came in last. These applications were consolidated and set down for hearing together. When the consolidation application was called, counsel for Vinci Orascom however informed the court of their withdrawal thus leaving CSC as the only applicant. ${ }^{176}$ The contract was awarded in March 2013 but did not begin with implementation as court proceedings began in the High Court.

\footnotetext{
174 Schimdt 2014:48.

175 (A 109/2013 and A 76/2013) [2013] NAHCMD 186 (4 July 2013).

176 Para 5.
} 
The matter was brought before the Windhoek High Court of Namibia and judgment was only handed down on 4 July 2013 that same year. The matter was reviewed by the High Court judges which resulted in the setting aside of the tender award. The Board was ordered to start the award process afresh and re-awarded the tender to the same company, Salini. The government, being the respondents, therefore lost the matter and were ordered to pay the applicants' costs, jointly and severally. In March this year, media reports ${ }^{177}$ revealed that the company that was re-awarded the tender, Salini, wanted to sue the government in the amount of $\mathrm{N} \$ 600$ million for delays caused by challenges made to courts. The court interference meant that the tender was not re-awarded until August, and work did not begin on site until September. In light of this delay, the project start date was still not amended and so Salini was said to be asking that the government pay the sum to compensate it for the delay. ${ }^{178}$ There is however no court case to date on this matter, but this is a clear illustration of what other expenses the government can potentially incur as a result of court interferences in public procurement cases.

Court cases are clearly undesirable as they delay the procurement process and should therefore be minimised. The occurrence of court cases will however not minimise due to the current lack of standard bidding documents in Namibia. Standard bidding documents, as previously stated, provide detailed evaluation criteria for all contracts. The current evaluation criteria are tailor made for each tender in Namibia ${ }^{179}$ and fall short of international standards set in this regard. The lack of standard bidding documents makes the procurement system susceptible to corruption as the evaluation criteria can easily be manipulated and increases the number of court cases. Important information regarding tenders are not required to be published and therefore various processes can be carried out in secrecy hence making it easy to veil corrupt activities. ${ }^{180}$ In an unreported controversial matter between Profile Investments (Pty) Ltd and The Chairperson of the Tender Board of Namibia and 3 others ${ }^{181}$, Profile

\footnotetext{
177 Haufiku, 2015.

178 Haufiku, 2015.

179 Amoo \& Dicken 2013:138.

180 Schmidt 2014:45.

181 Case No 1661, Windhoek High Court Main Division - in the matter between Profile Investments (Pty) Ltd (First Applicant) and Chairperson of the Tender Board of Namibia (First Respondent), The Minister of Works and Transport (Second Respondent), Oshana Wholesalers Close Corporation (Third Respondent) \& Voestalpine-VAE SA (Pty) Ltd (Fourth Respondent). Matter never went on trial as no arguments were advanced in opposition of the prayers sought by Profile Investments and therefore orders were granted in motion court. Order granted on 31 May 2013.
} 
Investments was initially recommended for a railway tender but was ultimately unsuccessful and therefore challenged the decision of the Board to be set aside. It alleged that the consultant advising on the best supplier, had manipulated the award criteria by designing the tender in such a way as to favour a specific company. ${ }^{182}$ The respondents in this matter advanced no arguments in opposition of the prayers sought by Profile Investments and therefore orders in favour of Profile were granted in motion court, resulting in the decision of the Tender Board being set aside and referred back for reconsideration. This clearly demonstrates that the current tailor made evaluation criteria is not efficient as such criteria can easily be manipulated and thus similar court cases will continue to rise if nothing is done about this. This adds to the waste of time and money in legal fees that government has to incur.

Having standard bidding documents which provide for detailed evaluation criteria would also help reduce the number of court cases as unsuccessful suppliers will know exactly on what grounds their bid was unsuccessful. Section 16 (1) (b) of the Tender Board of Namibia Act provides aggrieved suppliers with the right to request reasons for the acceptance or rejection of their tender from the Tender Board. Beyond this right to request reasons, there is however no other option to gain access to information about the evaluation process other than challenging it in court. ${ }^{183}$ This however can be quite a challenging task for the supplier when it comes to procurement. ${ }^{184}$ In an unreported judgement, New Era Investments (Pty) Ltd v The Roads Authority ${ }^{185}$ a supplier, in terms of Article 18, sought review of the first respondent (public authority) as to why it rejected the tender in favour of another supplier. The court held that there is no onus on the public official to justify its conduct and that the onus rests on the applicant supplier to satisfy that good grounds exist to review the conduct complained of. ${ }^{186}$ The Roads Authority relied on its line ministry, Ministry of Works and Transport, having procurement policies and rules that all its agencies have to take into consideration when evaluating bids. The court dismissed the application as the supplier failed to satisfy that good grounds exist for a review. Similar court cases can simply be prevented by having standard bidding documents in place.

\footnotetext{
182 Immanuel, 2013.

183 Schimdt 2014:50.

184 Quinot 2013:322.

185 (A05/2014) [2014] NAHCMD 56 (20 February 2014).

${ }^{186}$ Ambunda, 2014:81.
} 


\section{Out of pocket losses following the setting aside of a tender}

As previously mentioned, once a tender in Namibia has been awarded in compliance with the statutory provisions, all remedies sought thereafter are governed by the law of contract or the law of delict. ${ }^{187}$ The law of contract applies to the management of contracts concluded between the procuring authority and the successful supplier in which the innocent party is entitled to any of the general remedies under the law of contract for the breach of contract by the other party. ${ }^{188}$ The plaintiff in such a case bears the onus to prove the alleged breach of contract and is entitled to relief once he or she has proven that there has been a breach. ${ }^{189}$ The law of delict on the other hand pertains to any damages claims that may arise from procurement cases. A delict has been defined as the act of a person that in a wrongful and culpable way causes harm to another. ${ }^{190}$ Such a person can only be compensated by law if it is proven that he or she has suffered some loss or damage. ${ }^{191}$ The purpose behind this is to put the innocent party in the position he/she would have been in if no delict occurred. ${ }^{192}$ In terms of public procurement, damages may take various forms such as out-of-pocket expenses; loss of profits; or even the loss of a chance to bid for or win a tender. ${ }^{193}$

To date, there have been very little delict cases brought against the Government of Namibia under public procurement and therefore the courts have not been able to lay down principles on public procurement cases. ${ }^{194}$ Loss of profits in terms of a concluded procurement contract has been claimed before and requires all the elements of a delict to be proven. ${ }^{195}$ With regards to out-of-pocket expenses when a tender is set aside, there have been no reported judgements to date and therefore Namibia has no principle laid down on this kind of damages claim in respect of procurement cases. If the current system continues, the courts may end up with such

\footnotetext{
187 Amoo \& Dicken 2013:129.

188 Bolton 2007:357.

189 International Business Bureau (Pty) Ltd v Government of the Republic of Namibia (SA 45/2008)

[2011] NASC 4 (9 June 2011).

190 Neethling \& Potgieter 2010:4.

191211.

192217.

193 Bolton 2007:376.

194 Amoo \& Dicken 2013:129.

195 Serenity Manufactures v Minister of Health and Social Services 2007 (2) NR 756 (SC).
} 
claims in future as contracts awarded are expected to be concluded immediately after notification to the successful supplier. ${ }^{196}$ The successful supplier may then start with the execution of the contract immediately which of course has financial implications for the supplier. Should a contract be set aside and awarded to another supplier, the initial supplier incurs wasted costs on the execution of the initial tender award. The aggrieved supplier may approach the courts in terms of the law of delict to claim compensation as there are no laid down principles on procurement specific cases that prohibit such a claim in Namibia.

Namibia uses South African case law as persuasive value and the cases arising out of procurements contracts can easily be relied on by Namibian courts. The case of Eberhard Wolfgang Lisse $v$ The Minister of Health and Social Services ${ }^{197}$ concerned a damages claim against an organ of state. This case however did not relate to procurement. The High Court of Namibia in any event relied ${ }^{198}$ upon several South African judgements, in particular a procurement specific case of Steenkamp NO $v$ Provincial Tender Board, Eastern Cape. ${ }^{199}$ This case laid down the principle in South Africa that an organ of state is not liable in delict for a successful supplier's out-ofpocket losses following the setting aside of the tender because of a bona fide error on the part of the organ of state in the tender process. ${ }^{200}$ One of the grounds that the Constitutional Court relied on for not recognising such a claim was that the supplier in this case was held to have acted too quickly following the award of the tender. ${ }^{201}$ The Court argued that the supplier should have waited before it acted on the tender award to see if the award was not challenged on review. ${ }^{202}$ In terms of South Africa's Promotion of Administrative Justice Act, 3 of 2000 (PAJA), the review period provided is generally a maximum of 180 days after notification of a decision under PAJA. ${ }^{203}$ Although South Africa has no mandatory procurement standstill period, the 180 days is regarded to amount to such. ${ }^{204}$

In Namibia's case, there is no standstill period whatsoever. A contract is concluded immediately and can be reviewed any time thereafter. The question then is, how does

\footnotetext{
196 Tender Board of Namibia Act 16 of 1996 s 16(2).

197 (Case No 13891/2008) delivered on 23 August 2011.

198 Para 29.

19920073 SA121 (CC).

200 Quinot 2008:101.

201 Steenkamp NO v Provincial Tender Board, Eastern Cape 20073 SA121 (CC) paras 51-52.

202 Para 52.

203 PAJA s 7(1). This period may be extended either by agreement between the parties or by the Court. 204 Quinot 2013:318.
} 
one determine that a supplier has acted too quickly in Namibia? There is no mandatory standstill period required to be observed and therefore a successful supplier is expected to immediately begin preparations on the implementation of the contract which involves financial costs. Procurement transactions in any event require prompt execution as time is of the essence in the procurement process. So should a case arise in which a supplier successfully argues that he is entitled to out of pocket expenses, the courts may recognise this claim.

Another argument raised in Steenkamp against the recognition of such a claim was policy considerations, such as limited resources and that such liability would place too much of a burden on state treasury. ${ }^{205}$ In his article, "Worse than losing a government tender: Winning it", Quinot ${ }^{206}$ critically analyses this judgement and argues that such a judgment can have a negative effect on public procurement. Refusing such a claim would not only be unfair ${ }^{207}$ to the supplier but it would also deter potential suppliers from bidding for government contracts, which reduces the range of choices open to government. ${ }^{208}$ This reduces competition, which affects the quality of goods and services provided at the end of the day. It is therefore only just that suppliers are allowed to claim such damages for expenses incurred in the preparation of executing a contract that is now set aside due to factors they played no role in. The government will thus have to spend money on such claims, which is rightly just. The problem, however, will be the number of such claims the court will have to award, which of course is an additional constraint on the public purse. The chances of such claims are quite high as there is no standstill period and contracts already concluded are allowed to be challenged. Having a standstill period in place would at least reduce the number of such potential claims in Namibia.

\section{On the effectiveness of Namibia's supplier remedies regime}

The judicial review process as the only supplier remedies available, is clearly not effective as it causes disruption, which highly interferes with the entire procurement process. The courts do not have time limits within which decisions have to be made.

\footnotetext{
205 Steenkamp NO v Provincial Tender Board, Eastern Cape 20073 SA121 (CC) para 55(c).

206 Quinot 2008:101.

207112.

208112 n 91 (footnote omitted).
} 
This prolongs delays and can result in double expenses for government as illustrated by the Neckartal case. Judicial review is also quite expensive and therefore not all suppliers have access thereto, due to the high legal fees involved. The lack of detailed evaluation criteria unnecessarily increases the number of court cases as unsuccessful suppliers seeking reasons for their unsuccessful bids have no other option but to approach the courts as demonstrated by the New Era Investments case. The evaluation criteria can also easily be manipulated in this way, leading to an increase in corruption in the procurement process. Namibia should therefore find other means to address procurement disputes with the aim of reducing court cases. Comparative perspectives can be particularly helpful in Namibia's search for alternatives to which we turn next.

\section{Comparative perspectives}

\section{Introduction}

According to Quinot ${ }^{209}$ there is quite a great value in comparing the public procurement regimes of various countries as they can serve as a guiding mechanism for countries developing their procurement regimes. Since the Alcatel judgement, the mandatory standstill period has received international recognition and can therefore be found in various international instruments on public procurement. ${ }^{210}$ This has resulted in its incorporation into various procurement regulatory systems around the world. There are a number of African countries that have followed this international standard as well which include Kenya and Mauritius. The standstill periods vary from country to country. In Kenya it is 14 days $^{211}$ while it is 7 days in Mauritius. ${ }^{212}$ As previously mentioned, these two African nations are looked at as they are developing nations like Namibia and therefore they are more relevant to Namibia in terms of the same economic objectives. The UK which is a member of the EU is then looked at for new developments regarding the standstill period that Namibia can perhaps adopt to effectively implement the standstill period.

\footnotetext{
209 Quinot 2013:309.

210 See for example UNCITRAL Model Law Art 22.

211 Public Procurement Disposal Act (Kenya) s 68(2).

212 Public Procurement Disposal Act (Mauritius) s 40(4).
} 


\section{Kenya}

Kenya is a developing nation located in east Africa with a total population of $\mathbf{4 5 . 5 5}$ million and has been classified as a lower middle income country by the World Bank. ${ }^{213}$ The procurement regulatory framework has been described to be quite extensive, covering even defence procurement and the procedures provided for do not fall short of international best practices. ${ }^{214}$ This makes it a good example to look at. Public procurement in Kenya is regulated by the Kenya Public Procurement Disposal Act 3 of 2005. The purpose of the public procurement regime is provided for by section 2 of the Act which is to establish procedures for procurement and the disposal of unserviceable, obsolete or surplus stores and equipment by public entities to achieve specific objectives. These include value for money and efficiency ${ }^{215}$; transparency and accountability to the public; ${ }^{216}$ integrity; ${ }^{217}$ ensuring fair competition ${ }^{218}$ and finally increase public confidence in such procedures. ${ }^{219}$ These objectives are said to be in line with those provided for by the UNCITRAL Model Law. ${ }^{220}$ The Act regulates all aspects of the procurement process until an enforceable contract has come into existence. ${ }^{221}$ The execution of the contract awarded is however governed by the common law principles of contract that are enforceable in the judicial courts of Kenya. ${ }^{222}$ To ensure that the various rules and guidelines regulating procurement are adhered to, the Act provides for administrative review of procurement procedures contained in sections 93 to 100 of the Act. Compared to Namibia, Kenya's enforcement mechanisms are provided for at an administrative level and not only at judicial level. It is therefore reasonable to contend that suppliers in Kenya have more access to justice as the administrative review mechanism is cheaper compared to

\footnotetext{
213 The World Bank Group, 2015.

214 Udeh 2013:121.

215 Public Procurement Disposal Act (Kenya) s 2(a).

$216 \mathrm{~S} 2(\mathrm{~d})$.

$217 \mathrm{~S} 2$ (c).

218 S 2(b).

219 S 2(e).

220 Udeh 2013:102.

221107.

222107.
} 
judicial review which involves high legal fees that not all suppliers can afford. This administrative review process is headed by a review board. ${ }^{223}$

The notification of the award of contract is provided for by section 67 (2) and states that at the same time the successful supplier is notified of the award contract, the procuring entity shall notify all other suppliers that their tenders were not successful. The notification is not required to contain the reasons behind the decision of an award contract. An aggrieved supplier may then seek administrative review if so desired in the manner prescribed by the Act. ${ }^{224}$ Some matters relating to the procurement process are however exempted from review such as the choice of a procurement procedure; ${ }^{225}$ a decision by the procuring entity under section 36 to reject all tenders, proposals or quotations; ${ }^{226}$ and properly concluded contracts. ${ }^{227}$ Frivolous appeals are also exempted from review. ${ }^{228}$ Compared to Namibia, contracts already concluded are not allowed to be challenged and as such reduces disruptions in the procurement process. As previously mentioned, the Act only governs the procurement process until an enforceable contract has come into existence. ${ }^{229}$ The review board suspends the procurement proceedings complained of until a decision is reached. ${ }^{230}$ This is done because if proceedings are not suspended, the procuring entity concerned may move onto signing the contract, at which point the matter will fall outside the jurisdiction of the Act. ${ }^{231}$ It is for this reason that a standstill period has been provided for in the Kenyan public procurement regime. Section 68 (2) provides a standstill period of exactly 14 days. A contract can only be entered into between the successful supplier and the procuring authority after the 14 days have lapsed. The standstill period is said to run from the date on which the successful supplier has been notified simultaneously with the unsuccessful suppliers of their unsuccessful bid. ${ }^{232}$ In Mits Electrical Company Ltd $v$ Office of the President and Ministry of Lands and Housing ${ }^{233}$ it was held that the 14 day period begins to run on receipt of notice of award by suppliers and not on

\footnotetext{
223107.

224 Public Procurement Disposal Act (Kenya) s 93(1).

225 S 93(2)(a).

$226 \mathrm{~S} 93(2)(\mathrm{b})$.

$227 \mathrm{~S} 93(2)(\mathrm{c})$.

228 S 93(2)(d).

229 Udeh 2013:107.

230108.

231 Public Procurement Disposal Act (Kenya) s 93(2)(c).

232 S 67(2).

233 Applications 3/2005 and 6/2005.
} 
issuance of the notice. Challenges to the award decision are then only allowed to be lodged within this 14 day period as contracts concluded are not allowed to be challenged.

The review board is required to complete its review within 30 days after receiving a request from an aggrieved bidder for the review. ${ }^{234}$ Upon completion of the review, the board may annul any decisions of the procuring authority, refer the matter back for reconsideration or substitute a decision of the board and finally order the payment of costs as between parties to the review. ${ }^{235}$ The Act is silent on whether the review board can also make compensation awards as provision is only made for orders regarding payment of costs between parties to the review. ${ }^{236} \mathrm{~A}$ decision by the review board is held final and binding on the parties unless judicial review thereof commences within 14 days from the date of the board's decision. ${ }^{237}$ The decision of the board is therefore appealable to the High Court, but the High Court's decision is final and not appealable. ${ }^{238}$ Furthermore, it is provided that if a judicial review is not declared by the High Court within 30 days from the date of filing, the decision of the review board shall take effect. ${ }^{239}$

In comparison with Namibia, Kenya's supplier remedies are more advanced as they meet international standards. Kenya has an administrative review mechanism set in place to specifically deal with all actions pertaining to public procurement as proposed by the UNCITRAL Model Law on procurement. The review board has time limits within which a review has to be completed. This serves as a good mechanism of ensuring that the procurement process is carried out swiftly as time is of the essence. Contracts are then concluded and the successful supplier can effectively implement the contract with no disruptions. This in turn promotes efficiency of the procurement process as no money is wasted on projects that have started running operation already just for them to come to a halt because of court interferences like the case in Namibia. Having an administrative review mechanism decreases the number of cases that end up in judicial review which can be viewed as a good thing as judicial interference can be quite costly due to delays. ${ }^{240}$ Public funds are therefore used more efficiently in Kenya.

\footnotetext{
234 Public Procurement Disposal Act of Kenya s 97(1).

235 S 98.

$236 \mathrm{~S}$ 98(d).

237 S 100(1).

238 S 100(2).

239 S 100(4).

240 Gordon 2006:437.
} 


\section{Mauritius}

Mauritius has been classified as a developing upper middle-income country by the World Bank with a population of 1.3 million. ${ }^{241}$ The country has had wide ranging reforms since 2006 and is anchored by robust policies and has become one of the most competitive economies in Sub-Saharan Africa. ${ }^{242}$ According to Tjirera, ${ }^{243}$ Mauritius has one of the most robust public procurement systems on the African continent and therefore serves as a good example for any country reforming its procurement regulatory framework. Public procurement in Mauritius is regulated by the Public Procurement Act 3 of 2006. The government has used public procurement as an instrument to implement socio-economic objectives and environmental policies which include supporting SMEs amongst others. ${ }^{244}$ In 2013, as previously stated, SMEs became the main drivers of employment as they provided a living to $54 \%$ of the population. ${ }^{245}$ The Mauritian government therefore tries to support these entities through preferential treatment and reservations.

Mauritius, like Kenya, provides for an administrative review mechanism for aggrieved suppliers, but operates differently. Section 40 of the Act provides for the award of procurement contracts. The procuring authority is expected to notify the successful supplier in writing of the selection of its bid for award and a notice in writing is to be given to the unsuccessful suppliers specifying the name and the address of the proposed successful supplier and the price of the contract. ${ }^{246}$ Like Kenya, reasons behind the selection are however not required to be part of the notification. Suppliers seeking reasons behind their unsuccessful bids can only get such information after notification of the successful supplier. ${ }^{247}$ The standstill period of 7 days is provided for by section 40 (4) which states that in the absence of a challenge by any other supplier within 7 days of the date of the notice, the contract shall be awarded to the successful supplier.

\footnotetext{
241 The World Bank Group, 2015.

242 African Development Bank Group, 2015.

243 Tjirera, 2011:6.

244 Procurement Policy Office, 2014:7.

2457.

246 Public Procurement Act (Mauritius) s 40(3).

247 S 41.
} 
Section 43 (1) makes provision for challenges and states that a supplier who claims to have suffered, or is likely to suffer loss or injury due to a breach of a duty imposed on a public body may challenge the procurement proceedings before the entry into force of the procurement contract. This means that challenges are also not allowed after the conclusion of the award contract. Any aggrieved supplier must challenge such an award before the standstill period of 7 days has lapsed. The challenge is made in writing to the Chief Executive Officer of the public body concerned identifying the specific act or omission alleged to contravene the Act. ${ }^{248}$ The proceedings are suspended by the Chief Executive Officer who is then required to issue a written decision with reasons within such a time as may be prescribed. ${ }^{249}$ This is the first stage of review. If the supplier is unsatisfied with this decision, an appeal can be lodged to the review panel under section 45. This review panel consists of members with expertise in legal, administrative, economic, financial, engineering, scientific and technical matters. ${ }^{250}$ The review panel may dismiss the application or if it determines that there is merit in it, it may either prohibit the public body from taking further action that contravenes the Act; ${ }^{251}$ recommend an annulment in whole or in part of any unauthorized act of decision of the public body; ${ }^{252}$ recommend a re-evaluation of bids or review of the decision; ${ }^{253}$ or recommend payment of reasonable costs incurred in participating in the bidding process where a legally binding contract has been awarded which, in the opinion of the panel, should have been awarded to the applicant. ${ }^{254}$ The matter then ends here with no court interferences.

Where the challenge is upheld, the corrective measures to be taken have to be stated as well. ${ }^{255}$ In terms of section 45 (3) (a) an applicant for a review is required to make a deposit as may be prescribed for the filling of the application. This deposit may be forfeited in cases where the review panel decides that the application is frivolous. ${ }^{256}$ In cases where the review panel decides that there is no merit in the application, 50 percent of the deposit shall be forfeited. ${ }^{257}$ This can be seen as a mechanism in

\footnotetext{
248 S 43(1).

249 S 43(4).

250 S 44(1).

251 S 45(10)(a).

252 S 45(10)(b).

253 S 45(10)(c).

${ }^{254} \mathrm{~S} 45(10)(\mathrm{d})$.

255 S 43(4).

256 S 45(3)(b).

257 S 45(3)(d).
} 
deterring suppliers who simply wish to delay the procurement process with no reasonable grounds of review. Unnecessary delays are also prevented in this manner. Public officials who contravene the Act are held to have committed an offence and on conviction are liable to a fine and to penal servitude for a term not exceeding 8 years. ${ }^{258}$ This indeed is a good way of ensuring that public officials carry out their mandate in terms of the laws applicable as they know that they can personally be held accountable. This is not the case in Namibia as the Ministry of Finance is held accountable for the misconduct performed on the part of procuring officials which has no deterring effect on the public officials themselves. Compared to Kenya, the 7 days standstill period in Mauritius is shorter than the 14 day period in Kenya and it can therefore be implied that the procurement process is operated at a faster rate in Mauritius. This of course is beneficial to the entire procurement process as time is of the essence and suppliers on the other hand are also afforded an opportunity to challenge an award decision before its conclusion. Whether this time period is sufficient or not depends on the information issued out on the notifications. The more detail that is given, the faster suppliers can challenge an award decision as suppliers can easily collect information to challenge the award decision. Having standard bidding documents in place also helps with the easy collection of information regarding the selection criteria and both Kenya ${ }^{259}$ and Mauritius ${ }^{260}$ use standard bidding documents provided for by the World Bank Model Law.

\section{United Kingdom}

As a member of the EU, the UK is bound by the Public Contracts Directives (2014/24/EU). In the UK, these Directives are implemented by the Public Contracts Regulations 2015 which recently came into force in February 2015 replacing the old ones. ${ }^{261}$ It should be noted that the regulatory framework of the EU is clearly at a more advanced level with more provisions as it has different needs to those of any developing nation. For the purposes of this study, the standstill period and the rules regulating its implementation are therefore the only focus. The aim of this is to see

\footnotetext{
258 S 60.

259 Available at $<$ http://www.ppoa.go.ke/index.php?option=com_content\&view=article\&id=224> .

260 Available at <http://ppo.govmu.org/English/Pages/Standard-Bidding-Documents.aspx>.

261 Crown Commercial Service, 2015:2.
} 
whether there are any rules that Namibia can adopt when implementing the standstill period in its regulatory framework. As has been stated, the EU has one of the best regimes which can serve as a guiding mechanism for countries developing their own procurement regimes. ${ }^{262}$

Chapter 5 of the UK Regulations provides for the facilitation of remedies applicable to public contracts. ${ }^{263}$ The contracting authority is required to send to each candidate $^{264}$ and tenderer ${ }^{265}$ a notice communicating its decision to award a contract or conclude a framework agreement. ${ }^{266}$ An interesting provision is regulation 86 (2) which provides for the content of notices to be send out. The UK regulation does not only require the notice to contain the particulars of the successful candidate or tenderer, ${ }^{267}$ but also the criteria for the award of the contract ${ }^{268}$ and the reasons for the decision including the characteristics and relative advantages of the successful tenderer. ${ }^{269}$ The relative advantage information is not applicable when the notice is sent to a candidate. ${ }^{270}$ The rule regarding reasons to be sent out with the notification was adopted from an Irish case of Commission $v$ Ireland. ${ }^{271}$ The question on when exactly the standstill period should start running was decided on. The standstill period in Ireland initially began from the moment the unsuccessful bidder was informed of the award decision, not from the moment when, on his request, he was informed of the reasons for awarding the contract to another supplier. ${ }^{272}$ The court held that reasons for rejecting a tender must be communicated at the time of notification of the decision to allow an unsuccessful bidder to properly challenge a decision within the time limit afforded by the standstill period. ${ }^{273}$ Member states of the EU, including the UK, took recognition of this rule and therefore had to incorporate it into their national legislation. ${ }^{274}$

\footnotetext{
262 Arrowsmith 2009:252.

263 UK Regulations Reg 85.

264 Defined as an economic operator that has sought an invitation or has been invited to take part in a restricted procedure, a competitive procedure with negotiation, a negotiated procedure without prior publication, a competitive dialogue or an innovation partnership in terms of Reg 2(1).

265 Defined as an economic operator that has submitted a tender in terms of Reg 2(1).

266 UK Regulations Reg 86(1).

267 Reg 86(2)(c).

$268 \operatorname{Reg} 86(2)(a)$.

269 Reg 86(2)(b).

270 Reg 86(4)(b).

271 Case C-455/08.

272 Caranta 2011:76.

273 Case C-455/08, para 31.

274 Caranta 2011:76.
} 
Regulation 87 contains the standstill period and states that where regulation 86 (1) applies, the contracting authority is not allowed to enter into the contract or conclude a framework agreement before the end of the standstill period. Where the notice is sent through facsimile or electronic means, the standstill period ends at midnight at the end of the $10^{\text {th }}$ day after the relevant sending date of the notice. ${ }^{275}$ In cases where the notice is sent by other means, the standstill period ends at whichever of the following occurs first. Either at midnight of the end of the $15^{\text {th }}$ day after the relevant sending date of the notice ${ }^{276}$ or at midnight at the end of the $10^{\text {th }}$ day after the date on which the last of the economic operators (suppliers) to receive such notice receives it. ${ }^{277}$ Suppliers can therefore bring an action against individual contracting authorities in the High Court, as the court of first instance, within the set time periods. ${ }^{278}$ The general time limits for starting proceedings are set out in regulation 92 and 93 . By properly adhering to the standstill period, authorities can protect themselves from potential ineffectiveness claims, which in essence is a very serious post-contractual remedy. 279

There are three main grounds for ineffectiveness listed in regulation 99 of which sub regulation (5) (a) (i) provides that a contract concluded without properly applying the standstill period will be held ineffective. The consequences of ineffectiveness are provided for in regulation 101. It is stated that where a declaration of ineffectiveness is made, ineffectiveness should be considered prospectively, but not retrospectively, ineffective from the time when the declaration is made and, accordingly, those obligations under the contract which at that time still have to be performed are not to be performed by the supplier who initially won the contract. ${ }^{280}$ Contracts awarded without properly adhering to the standstill period are therefore not invalidated, but simply held to be ineffective from the date ineffectiveness is declared. This in terms of using public funds resourcefully is a good measurement as money spent already on the contract does not go to waste. The contract is simply carried on by another supplier. The court is then empowered to address issues of restitution and compensation as between those parties to the contract so as to achieve an outcome

\footnotetext{
275 UK Regulations Reg 87(2).

276 Reg 87(3)(a).

277 Reg 87(3)(b).

278 Crown Commercial Service, 2015:12. See also UK Regulations Reg 91 (2).

279 Crown Commercial Service, 2015:3.

$280 \operatorname{Reg} 101(1)$.
} 
which the court considers to be just in all the circumstances. ${ }^{281}$ Penalties in addition to, or instead of ineffectiveness are provided for by regulation 102 which in respect of the standstill period states that where a court makes a declaration of ineffectiveness, it must also order that the contracting authority pay a civil financial penalty of an amount to be specified in the order. ${ }^{282}$ This is a good measure as contracting officials know that there are consequences for which they will personally be held accountable for if they do not follow the correct procedures.

\section{Comparative conclusions}

It can be observed that all three procurement regimes have incorporated the standstill period into their domestic laws and therefore meet internationally set standards in this regard. The UK compared to Kenya and Mauritius is of course at a more advanced level. Both Kenya and Mauritius can perhaps adopt the rule on giving reasons as to the decision of rejecting a bid when the award notice is issued. This allows unsuccessful suppliers to properly challenge a decision within the time limit afforded by the various standstill periods. Information is easily collected this way which leads to an efficient review process.

Judicial interference in the public procurement process is clearly unsuitable especially in developing economies as it leads to the waste of scarce resources. In this regard, both Kenya and Mauritius have administrative review mechanisms where the review process starts. In Kenya, the decisions of the review board are appealable in the High Court and the matter ends there. Judicial interference in Kenya thus only comes into play at the appeal stage of which the occurrence is less compared to cases challenged for the first time at the review board. The presence of judicial interference in Mauritius is close to none existent in its procurement review procedure as it has an independent review panel made up of experts in various fields relating to procurement that deal with appeals and have the final say. Countries with no administrative review mechanisms can therefore adopt similar review structures as they reduce the waste of resources usually incurred with judicial interference in the public procurement process.

\footnotetext{
${ }^{281} \operatorname{Reg} 101(4)$.

${ }^{282} \operatorname{Reg} 102(2)(b)$.
} 


\section{Conclusion and Recommendations}

This paper sought to critically analyse the implications of section 16 (2) of the Tender Board of Namibia Act which allows for the conclusion of an award contract immediately after the successful supplier has been notified with no observation of a standstill period. This means unsuccessful suppliers are not afforded the opportunity to see whether the correct procedures were followed or not leading up to the decision of the award. Consequently, contracts that have already been concluded between the procuring authority and the successful bidder are allowed to be challenged through judicial review. The paper therefore also assessed the judicial review mechanism as the only supplier remedies available to suppliers in the Namibian public procurement domain. The effect of section 16 (2) is that procurement contracts already concluded are disrupted by court interferences. The effect of court interferences on the procurement process was discussed in chapter 3 and was held to be unsuitable for various reasons. These include the fact that not all suppliers have access to justice and therefore the misconduct of some public officials is left without being corrected. This can lead to the further misuse and waste of funds by public officials as corrupt activities lead to substandard work in some instances. Secondly, court interferences cause huge delays in the entire procurement process which at the end of the day lead to high costs for government as seen with the Neckartal case. The fact that contracts already concluded may be set aside or invalidated puts the government at risk for potential compensation claims which at the moment have no laid down principles to regulate them in the event they do occur. Judicial review, as the only supplier remedies available to aggrieved suppliers is therefore not cost-effective and other supplier remedies should be considered.

Having efficient supplier remedies in place is important as it creates an environment friendly for suppliers. A friendly environment attracts suppliers and this promotes competition which is an important aspect of public procurement. Competition has been identified as an important mechanism commonly used in public procurement systems, alongside transparency to achieve an efficient procurement system. ${ }^{283}$ Not only will an efficient procurement environment attract more local suppliers, but also international suppliers who may wish to trade with Namibia. Some writers are of the view that

283 Quinot \& Arrowsmith 2013:19. 
opening up markets to international trade when it comes to procurement is not something African countries prioritise as they are still developing and wish to empower their own people before international suppliers. ${ }^{284}$ This indeed is true as no African country has signed the World Trade Organisation Agreement on Government Procurement (WTO GPA) to date. 285 The aim of this agreement is to open up government contracts of all its member states to the international market. ${ }^{286}$ However, as a developing country, the necessary skills and qualifications to carry out certain projects will not always be available in the domestic market. The government through procurement also wants value for money, which amongst others means ensuring that the goods acquired are suitable and meet the requirements for the task in question. ${ }^{287}$ This means quality and in some instances, the international market can provide this quality when the domestic market cannot and it is therefore one of the reasons why an efficient procurement system must be developed that provides for effective supplier remedies.

\section{Recommendations}

The Namibian public has, over the years, called for changes to the manner in which the government procures goods and services as the process is generally perceived to be flawed and open to manipulation when it comes to the awarding of contracts. ${ }^{288}$ Namibia currently plans on reforming its public procurement system with the new Procurement Bill, which was tabled in the National Assembly on 15 September 2015 by the Finance Minister, Calle Schlettwein. This was done after the proposed draft Bill was called back by the new Namibian President, Dr. Hage Geingob, who came into office in March this year. ${ }^{289}$ The new Procurement Bill is the revised version of the draft Procurement Bill which was withdrawn from parliament in October 2013, due to various concerns expressed by lawmakers at the time. ${ }^{290}$ The new Procurement Bill aims to bring the Namibian procurement regulatory framework in line with international

\footnotetext{
284 De le Harpe 2009:191.

285 World Trade Organisation, 2015.

286 Provided for in the Preamble of the revised WTO Agreement on Government Procurement.

287 Quinot \& Arrowsmith 2013:9.

288 New Era Staff Reporter, 2015.

289 Government of the Republic of Namibia, 2015:18.

290 New Era Staff Reporter, 2015.
} 
standards. It aims to provide for the bidding process, bid challenges and reviews, and the employment of Namibian citizens amongst others. The Procurement Bill is also intended to have wider application as all public entities including parastatals and any other entities declared as public entities in terms of section 5 will be covered. This indeed is a good step in ensuring that all public funds used in the procuring of goods, works and services are spent accordingly for their intended purposes and in line with international standards. The Procurement Bill plans on establishing a Procurement Policy Unit to advise the Minister of Finance on procurement related matters ${ }^{291}$ and a Central Procurement Board to replace the current Tender Board. ${ }^{292}$ The Central Procurement Board will consist of members who are suitably qualified and proper persons having knowledge and experience relevant to the function of the Board. ${ }^{293}$

The bidding process is made provision for in Part 6, sections 39 to 57 . Section 55 provides for the awarding of procurement contracts. The accounting officer will be required in writing to notify the successful supplier and unsuccessful suppliers of the award specifying the name and address of the successful supplier and the price of the contract. ${ }^{294}$ Subsection 5 of section 55 introduces a standstill period of 7 days to be observed by all parties before a contract is concluded between the procuring body and the successful supplier. Reasons for the unsuccessful bid of a supplier will only be given upon request by the unsuccessful supplier and the accounting officer will be required to promptly do so. ${ }^{295} \mathrm{~A}$ standstill period will thus come into operation once the Procurement Bill is passed and therefore contracts properly concluded in terms of the law will not be allowed to be challenged anymore. Indeed this is a milestone in pursuance of protecting the government from civil litigation which costs the government a lot of money as the timely implementation of projects is affected. The question then is, is the period of 7 days sufficient for the unsuccessful suppliers to collect all the information required in order to decide whether to initiate review or not? In Mauritius it seems to be working. But it is hereby proposed that reasons for the unsuccessful bid should also be sent out in the notification notifying the suppliers of the award decision as it is done in the UK. This will enable suppliers to properly collect all information required in deciding whether to initiate a review or not. This of course

\footnotetext{
291 Procurement Bill (Namibia) s 6.

292 S 8.

293 S 11(1)(b).

294 S 55(4).

295 S 57.
} 
can only be achieved once Namibia starts using standard bidding documents, which section 43 of the new Procurement Bill requires to be made use of. Standard bidding documents contain detailed evaluation criteria and therefore the collection of information regarding the evaluation criteria used will easily be accessible this way.

The challenge and review procedure is made provision for in Part 7, sections 58 to 61. Judicial review as the only supplier review mechanism is not ideal and it is therefore recommended that Namibia adopt a review mechanism at an administrative level, in terms of which aggrieved suppliers can seek relief before approaching the courts. In this regard, section 58 aims to establish a Review Panel which will adjudicate on applications for review; suspension, debarment and disqualification of suppliers; and any other matter referred to it for consideration. ${ }^{296}$ This will be a great improvement compared to having the judicial review mechanism as the only supplier remedies available. More suppliers will have access to justice this way.

Section 59 provides for the application of the review procedure and states that a supplier may apply to the review panel for review of a decision or action taken by the Central Procurement Board or a public entity. The application of review will only suspend the award once the application has been made and resolved in favour of suspension. ${ }^{297}$ The panel will be required to strive to make a decision within 7 days of receipt of the application or as soon as practically possible, but not later than 14 days. ${ }^{298}$ This in light of time being of the essence in public procurement is a great measurement. Time limits within which review should be finalised promote the timely implementation of contracts. It is important to have a balance between the protection of suppliers and the timely implementation of projects. This is an essential component of an efficient procurement procedure. Aggrieved suppliers will have to exhaust all administrative supplier remedies set forward under the new Procurement Bill before instituting any judicial action in the High Court. ${ }^{299}$ This is a mandatory provision which will ultimately reduce the number of court cases and thus reduce judicial interference in the procurement process. Upon receipt of an application for review, the review panel may make various decisions which are listed in section 60 and vary from dismissing

\footnotetext{
296 S 58(1).

297 S 59(2).

298 S 59(3).

299 S 59(4).
} 
the application, ${ }^{300}$ to ordering that the procurement proceedings be terminated and start afresh. ${ }^{301}$

The review panel may also set aside in whole or in part a decision or an action that is not in compliance with the procurement laws, other than any decision or action bringing the procurement contract into force. ${ }^{302}$ This means that where a contract has come into force without complying with the laws, the contract shall be declared to be invalid and set aside in whole. However, this is not suitable in cases where a supplier may have commenced with the implementation of the contract. In this regard, it is submitted that the Namibian procurement regulatory framework adopts the principle of ineffectiveness and its consequences. Contracts declared to be invalid should not be set aside completely as this leads to the waste of public funds. The Namibian regulatory framework can adopt the approach followed in the UK where the contract is considered to be prospectively, but not retrospectively, ineffective as from the time when the declaration is made. ${ }^{303}$ The remainder of the contract can simply be carried out by the next supplier and issues of restitution and compensation can be addressed between the parties. This is just. The government in this manner will, in any event, not spend so much on compensation costs due to the mandatory standstill provision which of course will reduce the number of cases challenged in court.

Section 78 provides for an indemnity provision and states that a member of the Board, review panel, a procurement committee or a bid evaluation committee, a procurement management unit and any staff member thereof will not be liable for any loss or damages caused as a result of an act or omission committed in good faith, unless the loss or damage is attributed to the gross negligence or unlawful conduct of the member or staff member. This provision will reduce malpractices by public officials as they know that they may be held personally liable for damages claims in cases where the correct procedures are not followed. In comparison with the current Tender Board of Namibia Act, this is a great measurement in protecting the government from the waste of resources caused by public officials as there are no effective accountability provisions in place. The government is currently held vicariously liable for these malpractices.

\footnotetext{
$300 \mathrm{~S} 60(\mathrm{a})$.

$301 \mathrm{~S} 60(\mathrm{f})$.

${ }^{302} \mathrm{~S} 60(\mathrm{c})$.

${ }^{303}$ UK Regulations Reg 101.
} 
There is no doubt that in order to achieve the desired results, Namibia not only requires the reformation of its laws but also requires skilled personnel in order to implement the provisions of the proposed Procurement Bill. ${ }^{304}$ In this regard, there are plans to make arrangements with institutions providing tertiary education for the inclusion of courses on public procurement management with a view of ensuring that Namibia has trained professionals to perform procurement functions. ${ }^{305}$ Public procurement has picked up momentum locally in the past few years and therefore it is only wise to have the necessary infrastructure in place for its successful operation which uses public funds wisely. The aim here is to prevent another saga like the infamous Neckartal dam case and this can only be achieved by introducing a standstill period. The standstill period should, however, afford suppliers with sufficient time in gathering information necessary to decide whether to initiate review or not and at the same time ensure that the procurement process is not unnecessarily delayed.

304 Tender Board of Namibia, 2015:17.

30517. 


\section{Bibliography}

\section{Books}

Arrowsmith, S. 2005. The Law of Public and Utilities Procurement. 2nd ed. London: Sweet \& Maxwell.

Arrowsmith S., Linarelli, J. \& Wallace, D. 2000. Regulating Public Procurement: National and International Perspectives. The Netherlands: Kluwer Law International.

Arrowsmith, S. \& Kunzlik, P. 2009. Social and Environmental policies in EC Procurement Law: New Directives and New Directions. United Kingdom: Cambridge University Press.

Belda, P. 2007. Namibia. Madrid: Ebizguides.

Bolton, P. 2007. The Law of Government Procurement in South Africa. Durban: LexisNexis.

Burns, Y. 2013. Administrative Law. $4^{\text {th }}$ ed. Durban: Lexis Nexis.

Fox, W. \& Bayat, M.S. 2007. A guide to Managing Research. Cape Town: Juta \& Co. Hayes, P., Silvester, J., Wallace, M. \& Hartmann, W. (Eds.). 1998. Namibia Under South African Rule: Mobility and Containment. Ohio: Ohio University Press.

Hoexter, C. 2012. Administrative Law in South Africa. $2^{\text {nd }}$ ed. Claremont: Juta \& Co.

Kangumu, B. 2011. Contesting Caprivi, A History of Colonial Isolation and Regional Nationalism. Windhoek: John Meinert Printing.

Neethling, J., \& Potgieter, J.M. 2010. Law of Delict. $6^{\text {th }}$ ed. Durban: LexisNexis.

Thai, K.V. 2009. International Handbook of Public Procurement. United States: Taylor \& Francis Group LLC.

Trepte, P. 2004. Regulating Procurement: Understanding the Ends and Means of Public Procurement Regulation. United States: Oxford University Press.

Treumer, S. \& Lichere, F. 2011. Enforcement of the EU Public Procurement Rules. Denmark: DJǾF Publishing.

Quinot, G. \& Arrowsmith, S. (Eds.). 2013. Public Procurement Regulation in Africa. United Kingdom: Cambridge University Press.

\section{Chapters in Edited Collections}


Amoo, S.K. \& Dicken, S. 2013. The regulatory framework for public procurement in Namibia. In Quinot, G. \& Arrowsmith, S. (Eds.). Public Procurement Regulation in Africa. Cambridge University Press.

Arrowsmith, S. 2009. EC Regime on Public Procurement. In Thai, K.V. (Ed.). International Handbook of Public Procurement. United States: Taylor \& Francis Group LLC.

Bolton, P. 2013. The regulatory framework of public procurement in South Africa. In Quinot, G. \& Arrowsmith, S. (Eds.). Public Procurement Regulation in Africa. Cambridge: Cambridge University Press.

Caranta, R. 2011. Many different Paths, but Are They All Leading to Effectiveness?. In Treumer, S. \& Lichère, F. (Eds.). Enforcement of the EU Public Procurement Rules. Denmark: DJǾF Publishing.

Quinot, G. 2013. A comparative perspective on supplier remedies in African public procurement systems. In Quinot, G. \& Arrowsmith, S. (Eds.). Public Procurement Regulation in Africa. Cambridge: Cambridge University Press.

Quinot, G. 2013. Promotion of social policy through public procurement in Africa. In Quinot, G. \& Arrowsmith, S. (Eds.). Public Procurement Regulation in Africa. Cambridge:Cambridge University Press.

Treumer, S. 2011. Enforcement of the EU Public Procurement Rules: The State of Law \& Current Issues. In Treumer, S. \& Lichere, F. (Eds.). Enforcement of the EU Public Procurement Rules. Denmark: DJǾF Publishing.

Udeh, K.T. 2013. The regulatory framework for public procurement in Kenya. In Quinot, G. \& Arrowsmith, S. (Eds.). Public Procurement Regulation in Africa. Cambridge: Cambridge University Press.

\section{Theses or dissertations}

De le Harpe, S.P. 2009. Public Procurement Law: A comparative Analysis. LLD thesis. University of South Africa.

\section{Official publications}


Procurement Policy Office Mauritius 2013 Annual Report of the Procurement Policy

Office under the Minister of Finance and Economic Development (26-06-2014).

Namibia Public Procurement Reforms 2012/13-2013/4: Challenges and Achievements under the Tender Board of Namibia (16-04-2015).

\section{Law Journal articles}

Thai, K.V. 2001. Public Procurement Re-examined. Journal of Public Procurement 1:9. Gordon, D.I. 2006. Constructing a Bid Protest Process: The Choices That Every Procurement Challenge System Must Make. Public Contract Law Journal 35:427.

Schimdt, A. 2014. The need to reform the Namibian public procurement system: A comment on the Neckartal Dam saga. Namibia Law Journal 6:41.

Quinot, G. 2008. Worse than Losing a government tender: Winning it. Stellenbosch Law Review 19:101.

\section{Cases}

AFS Group Namibia (Pty) Ltd $v$ Chairperson of the Tender Board of Namibia (A55/2011) 2011 NAHC 184.

Alcatel Austria AG and Others v Bundeministerium fur Wissenschaft und Verkehr C $81 / 98$.

CSC Neckartal Dam Joint Venture $v$ The Tender Board of Namibia \& Others, (A109/2013; A76/2013) [2013] NAHCMD 186 (4 July 2013).

Commission v Ireland Case C-455/08.

Eberhard Wolfgang Lisse $v$ The Minister of Health and Social Services (Case No I3891/2008) delivered on 23 August 2011.

Erickson Motors (Welkom) Ltd v Protea Motors 1973 (3) SA 685 (A).

International Business Bureau (Pty) Ltd v Government of the Republic of Namibia (SA 45/2008) [2011] NASC 4 (9 June 2011).

Mits Electrical Company Ltd $v$ Office of the President and Ministry of Lands and Housing Applications No. 3/2005 and 6/2005, Public Procurement Complaints, Reviews and Appeals Board (Kenya) (1 March 2005). 
New Era Investments (Pty) Ltd v The Roads Authority (A05/2014) [2014] NAHCMD 56 (20 February 2014).

Profile Investments (Pty) Ltd and The Chairperson of the Tender Board of Namibia and 3 others Case No 1661 (31 May 2013)

Serenity Manufactures v Minister of Health and Social Services 2007 (2) NR 756 (SC).

Steenkamp NO v Provincial Tender Board, Eastern Cape 2007 (3) SA 121 (CC).

\section{Legislation}

\section{European Community}

Remedies Directive 2007/66/EC.

Public Contracts Directives (2014/24/EU).

\section{Kenya}

Public Procurement Disposal Act 3 of 2005.

\section{Mauritius}

Public Procurement Act 3 of 2006.

\section{Namibia}

Anti-Corruption Act 8 of 2003.

Tender Board of Namibia Act 16 of 1996.

\section{South Africa}

Promotion of Administrative Justice Act 3 of 2000.

\section{Subordinate legislation}

\section{Namibia}

High Court Rules of Namibia 2014.

Local Authority Tender Board Regulations GN R 30 in GG 2486 of 15-02-2001.

Regional Council Tender Board Regulations GN R 43 in GG 2492 of 05-03-2001.

Tender Board Regulations GN R 237 in GG 1403 of 02-09-1996.

The Tender Board of Namibia Code of Procedure 191 of 1997

Procurement Bill No. 8 of 2015.

\section{United Kingdom}


Public Contracts Regulations No. 102 of 05-02-2015.

\section{International Instruments}

United Nations Commission on International Trade Law (UNCITRAL) Model Law on Public Procurement 2011.

World Trade Organisation Agreement on Government Procurement.

\section{Internet sources}

African Development Bank Group, 2015. Mauritius. African Development Bank. Available at: <http://www.afdb.org/en/countries/southern-africa/mauritius/> [Accessed 31 March 2015].

Ambunda, L., 2014. Unreported High Court Civil Judgement Index 2014. Ejustice. Available at:

<http://www.ejustice.moj.na/High\%20Court/RegisterAndReports/RegisterAndReports /2014\%20Unreported\%20Civil\%20Judgment\%20Index.docx> [Accessed 10 August 2015].

Crown Commercial Service, 2014. A brief guide to the EU public Contracts Directive (2014). GOV.UK. Available at:

<https://www.gov.uk/government/uploads/system/uploads/attachment_data/file/4492 95/A_Brief_Guide_to_the_EU_Public_Contract_Directive_2014_-_July_2015.pdf> [Accessed 19 August 2015].

Crown Commercial Service, 2015. The Public Contracts Regulations 2015:

Guidance on the Standstill Period. GOV.UK. Available at:

<https://www.gov.uk/government/uploads/system/uploads/attachment_data/file/4179 45/Guidance_on_Standstill.pdf> [Accessed 19 August 2015].

European Commission, 2015. Remedies. European Commission, [online] 10 June. Available at: <http://ec.europa.eu/growth/single-market/publicprocurement/infringements/remedies/index_en.htm> [Accessed 18 August 2015].

Government of the Republic of Namibia, 2015. Republic of Namibia State of Nation Address by his Excellency Dr. Hage G. Geingob, President of the Republic of Namibia. Office of the President, [online] 21 April. Available at: <http://www.op.gov.na/> [Accessed 21 September 2015].

Graig, A., 2014. Saara wants better Tender Board. Informante, [online] 15 May. Available at: <www.informante.web.na/saara-wants-better-tender-board.13998> [Accessed 14 March 2015]. 
Haufiku, M., 2015. Salini demands extra N\$600 million from Government. New Era, [online] 16 January. Available at: <www.newera.com.na/2015/01/16/salini-demandsextra-n600m-govt-govt/> [Accessed 14 March 2015].

Immanuel, S., 2013. Government concedes $\mathrm{N} \$ 60$ million tender case. The Namibian, [online] 3 June. Available at:

<http://www.namibian.com.na/indexx.php?archive_id=108625\&page_type=archive_s tory_detail\&page $=859>$ [Accessed 6 August 2015].

Indongo, N., Maharero, T. \& Hangula, M., 2014. Research Report Assessing the Scope of Procurement and the Relevance of Procurement Financing in Namibia for SMEs. NamPro Fund. Available at:

<www.namprofund.com.na/attachments/article/66/ProcurementStudy.pdf> [Accessed 2 April 2015].

International Labour Organisation and the African Commission on Human and People's Rights, 2008. Examining Constitutional, Legislative \& Administrative Provisions Concerning Indigenous peoples in Namibia. Centre of Human Rights, University of Pretoria. Available at:

$<$ http://www.chr.up.ac.za/chr_old/indigenous/country_reports/Country_reports_Nami bia.pdf> [accessed 11 April 2015].

Jauch, H., Edwards, L. \& Cupido, B. Inequality in Namibia. Open Society Initiative for Southern Africa. Available at:

<http://www.osisa.org/sites/default/files/sup_files/chapter_3_-_namibia.pdf> [Accessed 11 April 2015].

Nakuta, J. \& Chipepera, F., 2011. Access to Justice. In Nakuta, J. \& Chipepera, F. The Justice Sector \& the Rule of Law in Namibia: Management, Personnel and Access. Namibia Digital Repository. Available at:

<http://projects.leadr.msu.edu/namibia/items/show/30> [Accessed 5 August 2015].

Namlex, 2010. Index to the Laws of Namibia. Legal Assistance Centre. Available at: $<$ www.lac.org.na/laws/pdf/namlex2010.pdf> [Accessed 10 April 2015].

New Era Staff Reporter, 2015. New Procurement Bill to be tabled in NA. New Era, [online] 11 September. Available at:

<https://www.newera.com.na/2015/09/11/procurement-bill-tabled-na/> [Accessed 21 September 2015].

New Era Staff Reporter, 2015. Schlettwein tables revised Procurement Bill. New Era, [online] 16 September. Available at: <www.newera.com.na/2015/09/16/schlettweintables-revised-procurement-bill/> [Accessed 21 September 2015].

OECD, 2011. Transparency in public procurement. In Government at a Glance 2011 (2011) OECD. Available at: <http://dx.doi.org/10.1787/gov_glance-2011-47-en> [Accessed 27 July 2015]. 
Office of the Auditor-General of the Republic of Namibia, 2014. What we do. Office of the Auditor-General. Available at: <http://www.oag.gov.na/service.html> [Accessed 6 August 2015].

Ombudsman Namibia, 2012. Mission. Ombudsman Namibia. Available at: <http://www.ombudsman.org.na/> [Accessed 6 August 2015].

Tender Board of Namibia, 2015. Public Procurement Reforms 2012/13-2013/4 Challenges and Achievements. Ministry of Finance, [online] 16 April. Available at: <http://www.mof.gov.na/documents/57482/62134/Public+Procurement+Reforms+20 12-2014.pdf/eb677000-02e6-4d2c-afb6-f497c73d08d6> [Accessed 6 August 2015].

The Common Wealth, 2015. United Kingdom. The Common Wealth. Available at: $<$ http://thecommonwealth.org/our-member-countries/united-kingdom>.

The World Bank Group, 2015. Data. The World Bank. Available at: <http://data.worldbank.org/cpontry/Kenya> [Accessed 10 August 2015].

The World Bank Group, 2015. Data. The World Bank. Available at: <http://data.worldbank.org/country/Mauritius> [Accessed 31 March 2015].

The World Bank Group, 2015. Data. The World Bank. Available at: <http://data.worldbank.org/country/namibia> [Accessed 10 August 2015].

Tjirera, E., 2011. Public Procurement in Namibia: The roles of codes of conduct in reducing corruption. Institute for Public Policy Research. Available at: <http://www.org.na/sites/default/files/IPPR\%20Paper\%20Four.pdf> [Accessed 31 March 2015].

World Trade Organisation, 2015. Agreement on Government Procurement: Parties, observers and accessions. World Trade Organisation. Available at: <https://www.wto.org/english/tratop_e/gproc_e/memobs_e.htm> [Accessed 26 September 2015]. 